\title{
Atypical IкB proteins in immune cell differentiation and function
}

Michaela Annemann ${ }^{1}$, Carlos Plaza-Sirvent ${ }^{1,2}$, Marc Schuster ${ }^{1,2, \#}$, Konstantinos KatsoulisDimitriou $^{1,2}$, Stefanie Kliche ${ }^{1}$, Burkhart Schraven ${ }^{1,3}$ and Ingo Schmitz ${ }^{1,2, *}$

${ }^{1}$ Institute of Molecular and Clinical Immunology, Otto-von-Guericke University, Leipziger Straße 44, 39120 Magdeburg, Germany

${ }^{2}$ Research Group of Systems-oriented Immunology and Inflammation Research, Helmholtz Centre for Infection Research, Inhoffenstraße 7, 38124 Braunschweig, Germany

${ }^{3}$ Department of Immune Control, Helmholtz Centre for Infection Research, Inhoffenstraße 7, 38124 Braunschweig, Germany

\# present address: Institute for Experimental Immunology and Imaging, University Hospital, University Duisburg-Essen, Hufelandstraße 55, 45147 Essen, Germany

* Corresponding author: Dr. Ingo Schmitz, Laboratory of Systems-oriented Immunology and Inflammation Research, Department of Immune Control, Helmholtz Centre for Infection Research, Inhoffenstr. 7, D-38124 Braunschweig, Germany, phone: +49 531 61813500, Fax: +4953161813599, E-mail: ingo.schmitz@helmholtz-hzi.de

Keywords: NF-kappaB, atypical IkappaB, immune system, macrophage, T cell 
Abbreviation: ARD, Ankyrin repeat domain; ANK, ankyrin repeats; Bcl-3, B cell lymphoma 3 protein; EAE, experimental autoimmune encephalomyelitis; ERK, Extracellular-signal-regulated kinase; FO, follicular; GC, germinal centre; IкB, inhibitor of

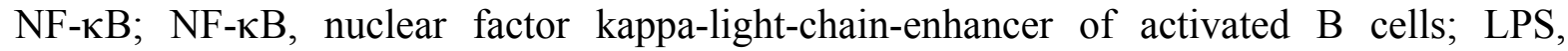
lipopolysaccharide; MZ, marginal zone, NLS, nuclear localization sequence; PP, Peyer's Patches; RHD, Rel homology domain; TAD, transcription activation domain; TCR, T cell receptor; TLR, toll like receptor

\begin{abstract}
The NF- $\mathrm{KB} /$ Rel signalling pathway plays a crucial role in numerous biological processes, including innate and adaptive immunity. NF- $\kappa \mathrm{B}$ is a family of transcription factors, whose

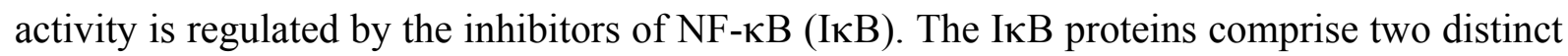
groups, the classical (cytoplasmic) and the atypical (nuclear) IкB proteins. Although the cytoplasmic regulation of NF- $\mathrm{KB}$ is well characterised, its nuclear regulation mechanisms remain marginally elucidated. However, work from recent years indicated that nuclear IкBs contribute significantly to the modulation of NF- $\mathrm{KB}-$ mediated transcription in the immune

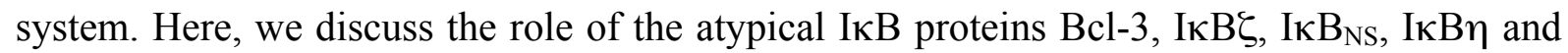
IкBL for the regulation of gene expression and effector functions in immune cells.
\end{abstract}




\subsection{Introduction to the NF- $\kappa$ B and IאB protein families}

The basis for today's knowledge about nuclear factor kappa-light-chain-enhancer of activated B cells $(\mathrm{NF}-\kappa \mathrm{B})$ was its discovery in 1986 as a regulator of $\kappa \mathrm{B}$ light chain expression in $\mathrm{B}$ cells [1]. Since that time, the function of the NF-kB transcription factor family was investigated in many research areas and the knowledge of NF-kB expanded rapidly involving

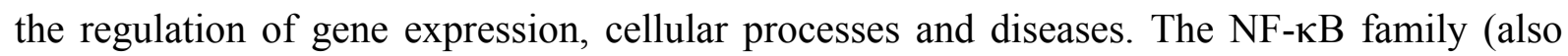
named Rel family) comprises 5 members termed p50/105, p52/100, p65 (RelA), c-Rel and RelB. They are characterised by an N-terminal Rel homology domain (RHD), which regulates dimerization and DNA-binding [2-4]. NF- $\kappa \mathrm{B}$ family members form homo- or heterodimers. Depending on the presence of a transcription activation domain (TAD) those dimers are able to activate or inhibit the expression of target genes [2-4]. Thus, due to their TAD homo- or heterodimers containing p65 (RelA), c-Rel or RelB enable the recruitment of co-activators and the expression of target genes whereas homo- or heterodimers of either p50 or p52 are thought to repress transcription (they lack a TAD). This is fine-tuned further by intracellular

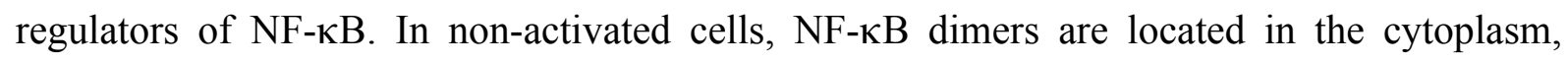
where they become functionally inactivated by classical members of the inhibitor of NF- $\mathrm{KB}$

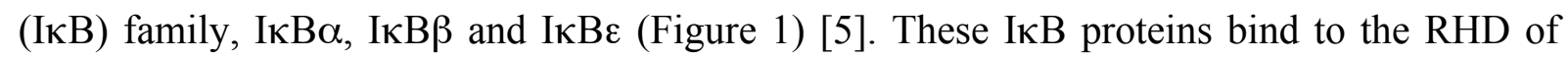
$\mathrm{NF}-\mathrm{\kappa B}$ and mask the nuclear localization sequence (NLS) within the RHD, preventing the nuclear localization of NF-кB dimers [5]. Upon cell activation, for example via the $\mathrm{T}$ cell

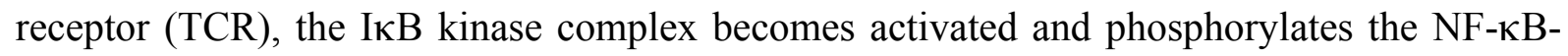

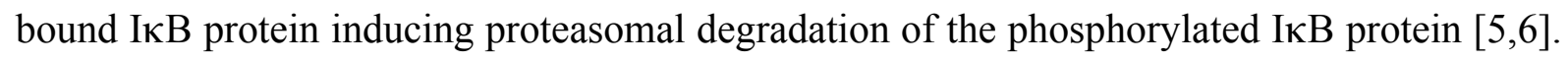
Thereupon, functionally active NF-אB dimers translocate into the nucleus and bind to specific $\kappa \mathrm{B}$-sites at the DNA. Each of the typical, cytoplasmic IкB proteins exhibits a diverse affinity to a specific NF-кB dimer and different kinetics of degradation, thus, enlarging the regulatory capacity of the five NF- $\kappa \mathrm{B}$ members $[3,5]$. 
An ankyrin repeat domain (ARD), containing six to eight single ankyrin repeats (ANK), is the common structural motif of all IאBs (Table 1 and Figure 1) [5]. Each ANK comprises 33 amino acids folded into a helix-loop-helix conformation [5]. The ARD is essential for protein stability and interaction with the RHDs of NF- $\mathrm{KB}$ dimers. N-terminal to the ARD, classical IкBs exhibit an unfolded structure with a signal response domain (also called degron motif), containing serine residues for stimulation-dependent phosphorylation by $\operatorname{IKK}[3,5,6]$. Furthermore, N-terminal to the phosphorylation sites of typical IкB proteins, lysine residues

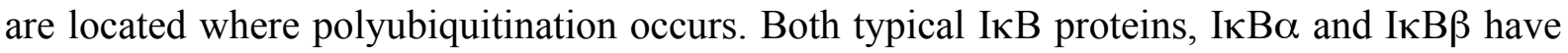
a region called PEST (rich in proline, glutamic acid, serine and threonine), which has been suggested to mediate fast protein turnover [5]. The NF- $\mathrm{BB}$ family members $\mathrm{p} 50$ and p52 originate from the precursors p105 and p100, respectively, which become post-translationally cleaved. Both, p105 and p100 contain C-terminal NF-кB-inhibiting ANKs as well as an N-

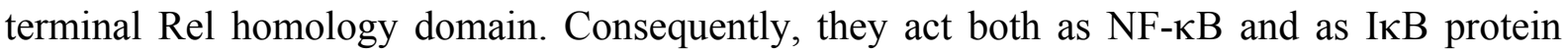
$[5,7]$.

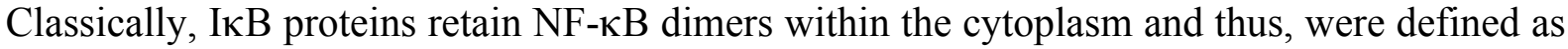

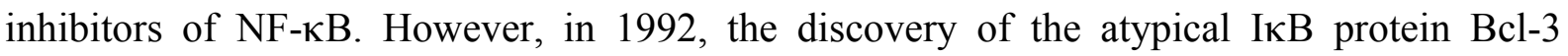

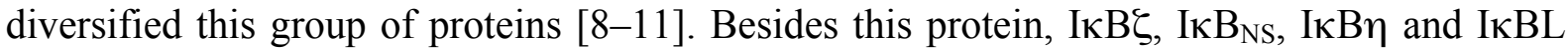
belong to the atypical or nuclear IкB proteins (Figure 1) [12-16]. Both, cytoplasmic and nuclear IкB proteins are characterized by ARDs, as mentioned before. Next to their nuclear

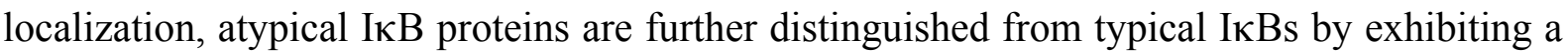

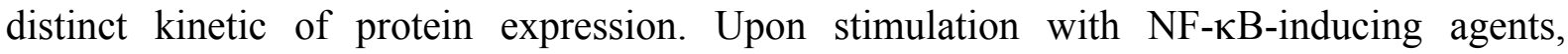

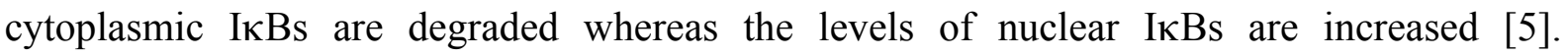
Interestingly, nuclear IкBs can inhibit target gene expression or act as enhancers for specific

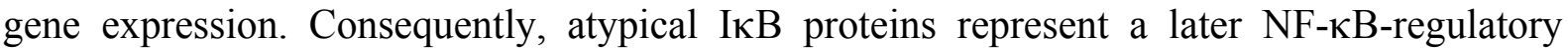




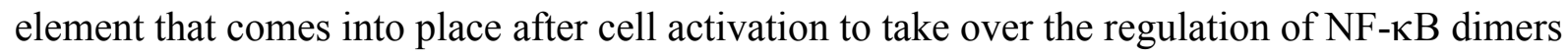

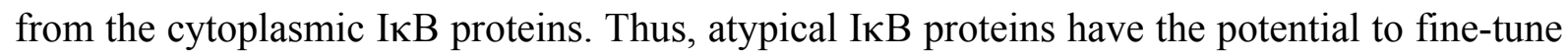
$\mathrm{NF}-\mathrm{\kappa B}$ activation and its transcriptional responses. Due to the heterogeneous activity of the atypical IкB proteins this review will highlight their function within major classes of immune cells (summarized in Table 2 and Figure 2).

\subsection{The members of the atypical, nuclear Iא B protein family}

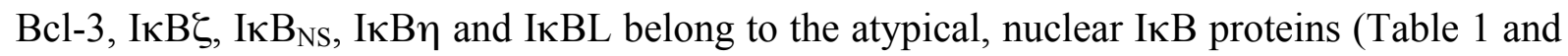
Figure 1). Mice deficient for a single nuclear IкB protein grow normally after birth, but, several defects of their organ structure and/or immune system were observed. Thus, mice deficient for nuclear IKB proteins suffer from autoimmune diseases and/ or show altered defence towards several pathogens, which will be outlined below.

\subsubsection{Bcl-3}

Bcl-3 (B-cell lymphoma 3 protein) was first identified as a proto-oncogene in patients suffering from B cell chronic lymphocytic leukaemia [17] and was later shown to interact with the NF-кB subunits p50 and p52 (Table 1) $[12,18,19]$. The expression of the seven ANK-containing protein is induced upon stimulation with lipopolysaccharide (LPS), IL-1 $\beta$, IL-4, IL-9, IL-10, IL-12 [20-26]. Bcl-3-deficient mice show a defect of splenic architecture, characterized by the absence of germinal centres within the white pulp of the spleen $[27,28]$. Beside the absence of germinal centres, intestinal Peyer's Patches (PP) are reduced in numbers [29]. Furthermore, Bcl-3-deficient mice are defective in clearing Listeria monocytogenes [27] and die of Streptococci pneumonia (associated with acute sepsis) [27] and Toxoplasma gondii infections [28,30]. In addition, Bcl-3-deficient mice do not suffer 
from spontaneous autoimmunity, but are more susceptible to the induction of type 1 diabetes [31].

\subsubsection{IKB $\zeta$}

Iк Bל (also known as INAP, MAIL or NFKBIZ) contains six ANK and its expression was first detected in several murine organs upon LPS-injection [13]. The expression of IкB $\zeta$ is upregulated by $\mathrm{B}$ cell receptor crosslinking as well as stimulation with $\beta$-glucan, Toll-like receptor- (TLR) ligands (CpG-DNA, bacterial lipoprotein, peptidoglycan, flagellin, MALP-2,

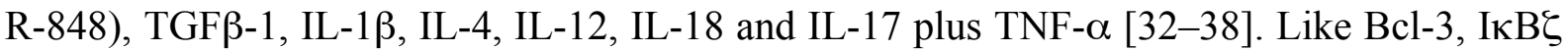
interacts with the NF- $\mathrm{KB}$ member p50 and additionally with p65 [33,34,39]. Mice defective for I $\mathrm{K} \mathrm{B} \zeta$ grow normally after birth but almost $90 \%$ of $\mathrm{I} \kappa \mathrm{B} \zeta$-deficient animals die during embryogenesis and adult mice suffer from spontaneous autoimmunity $[34,40]$. IкB $\zeta$-deficient mice develop an atopic dermatitis-like disease 10 weeks after birth as well as conjunctivitis [34,40,41]. Furthermore, I $\mathrm{\kappa B} \xi$-deficient mice are resistant to EAE (experimental autoimmune encephalomyelitis) induction upon immunisation with myelin oligodendrocyte glycoprotein (MOG)-peptide [42] but are highly susceptible to MCMV infections [38].

\subsubsection{IK $\mathrm{B}_{\mathrm{NS}}$}

The seven ANK-containing I $\mathrm{KB}_{\mathrm{NS}}$ (alternative names are NFKBID or TA-NFKBH) was first identified in studies of antigen-induced negative selection [14]. Similarly to peptides triggering negative selection, $\mathrm{I}_{\mathrm{N}} \mathrm{B}_{\mathrm{NS}}$ expression is induced by LPS, IL-10, anti-IgM, CD40

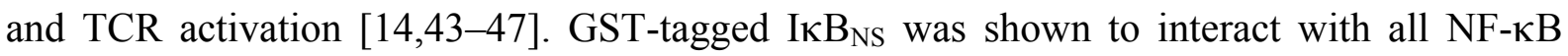
subunits in a pulldown analysis using thymic lysates [14]. Further analysis verified the interaction with p50 in RAW macrophages [44], as well as p50 and c-Rel in regulatory T (Treg) cells [43]. IкB $\mathrm{NS}_{\mathrm{NS}}$-deficient animals breed and grow normally. Two independent $\mathrm{I}_{\mathrm{B}} \mathrm{B}_{\mathrm{NS}^{-}}$ 
deficient mouse lines were investigated for germinal centre $(\mathrm{GC})$ formation with differing results. More specifically, sheep red blood cell immunisation resulted in defective GC formation in I $\kappa B_{\mathrm{NS}}$-deficient animals [47] whereas normal GC formation was observed upon immunisation with 4-Hydroxy-3-nitrophenylacetyl-Chicken Gamma Globulin (NP-CGG) [48]. In addition, the knockout of $\mathrm{I}_{\mathrm{K}} \mathrm{B}_{\mathrm{NS}}$ increased the susceptibility of mice to infection with Citrobacter rodentium [49] and influenza A virus [47]. Although $\mathrm{I}_{\mathrm{K}} \mathrm{B}_{\mathrm{NS}}$-deficient mice do not suffer from spontaneous autoimmunity and are more resistant to EAE induction [50], transfer of I $\mathrm{I}_{\mathrm{NS}}$-deficient T cells to RAG1-deficient animals resulted in an increased colitis $[43,49]$.

\subsubsection{IK $\mathrm{B \eta}$ and $\mathrm{I} \kappa \mathrm{BL}$}

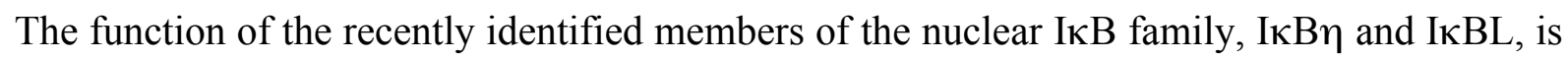

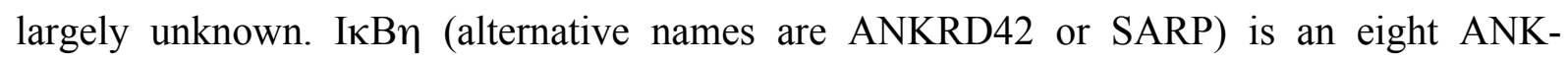
containing protein identified in gene expression analysis of bone marrow-derived DC [15,51].

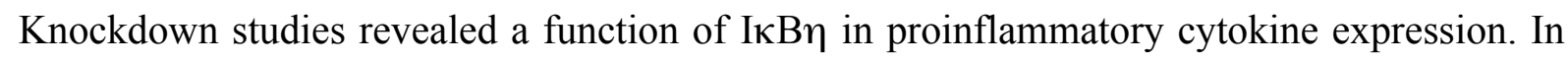

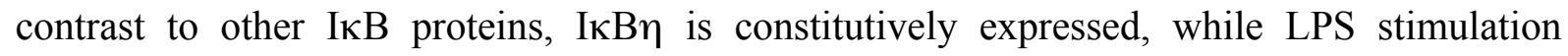

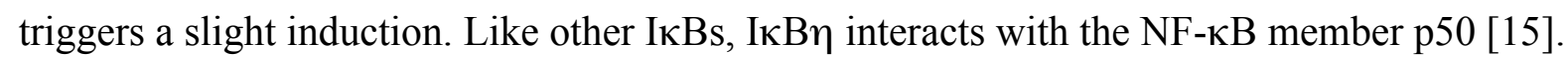

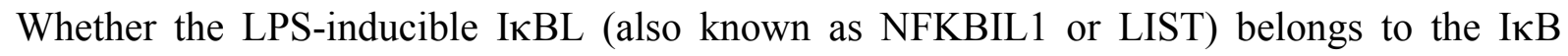
protein family is still under debate. Since IкBL contains two ANKs [16,52] and is localised within the nucleus [53] it was suggested that it belongs to nuclear IאBs but an interaction with NF-кB dimers was excluded [54]. Nevertheless, polymorphisms within the gene locus of IкBL are implicated in systemic lupus erythematosus, primary Sjögren’s syndrome, ulcerative colitis and rheumatoid arthritis [54-56]. 


\subsection{The atypical IкB protein family in macrophages}

Macrophages are a crucial cell type of the innate immune system. These phagocytes engulf and digest pathogenic microorganisms, cell debris, foreign substances and degenerated cells and link innate and adaptive immunity. The following section deals with the function of nuclear IкB proteins in macrophages (Table 1 and Figure 2A).

\subsubsection{Bcl-3 in macrophages}

Gram-negative bacteria express LPS as a major component of their cell wall. LPS is one of the strongest activators of macrophages and monocytes. LPS-stimulation of macrophages induces expression of pro-inflammatory cytokines including IL-6, IL-12 and TNF- $\alpha$. Upon LPS stimulation, Bcl-3-defective peritoneal macrophages exhibit an increased expression of TNF- $\alpha$. Accordingly lentiviral overexpression of Bcl-3 in RAW macrophages reduced the expression of TNF- $\alpha[22,24,57]$. Mechanistically, LPS caused the expression of IL-10 and this cytokine induced the expression of Bcl-3. Thereupon, Bcl-3/p50 binds to the TNF- $\alpha$ promoter and competes with the binding of transcription activating RelA and c-Rel [24]. Accordingly, RelA and c-Rel are bound to the TNF- $\alpha$ promoter in LPS-activated Bcl-3deficient macrophages [57]. Furthermore, Bcl-3 is not only expressed in a IL-10-dependent manner but also acts on IL-10 gene expression [22,57,58]. However, whether Bcl-3 inhibits or induces the expression of IL-10 is still controversially debated. Experiments with bone marrow-derived macrophages by Wessells and colleagues indicated an IL-10-expression supporting function and thereby an anti-inflammatory effect of Bcl-3 [22]. Nonetheless, publications by Carmody et al., Riemann et al. and Pène et al. showed the opposite result [5759]. Carmody and colleagues analysed the effect of LPS-stimulation in bone marrow derived macrophages, but revealed a negative regulation of IL-10 by Bcl-3 [57]. Whether these drastic differences arise from the strength of the LPS signal (different LPS concentration used) has to 
be further analysed. In the report by Riemann et al. Bcl-3 was shown to regulate IL-10 by inhibiting its gene expression in LPS-stimulated peritoneal macrophages [58]. Furthermore, studies on the activation of alveolar macrophages with LPS or heat-inactivated Klebsiella pneumoniae supported the assumption of an inhibitory effect of Bcl-3 to IL-10, but it has to be considered that LPS stimulation did not affect the expression of TNF- $\alpha$ in the Bcl-3deficient macrophages [59]. The expression of Bcl-3 was suggested to depend on the transcription factor STAT3. Hence, STAT3-deficient peritoneal macrophages did not induce Bcl-3 expression with or without IL-10 stimulation [24]. LPS stimulation of Bcl-3-deficient macrophages increased the level of the cytokine IL-1 $\beta$ and some chemokines (CXCL1, CXCL2, CCL2, CCL5 and CCL9), compared to wildtype cells [57]. Macrophages and their LPS-induced cytokines are essential in septic shock. In line with the ability of Bcl-3 to block LPS-induced cytokine expression by macrophages, wildtype mice reconstituted with Bcl-3deficient bone marrow are more sensitive to septic shock [57]. The splenic architecture of Bcl-3-deficient animals is disrupted and the macrophage population in the marginal zone of the spleen is at least partially lost, similarly to p52-deficient mice $[28,60]$. As mentioned above, Bcl-3 is able to bind to the p52 subunit of NF- $\mathrm{KB}$. In human cytomegalovirus infection, macrophages are the cells predominantly infiltrating the infected organ, but are also one of the most infected cell types. Macrophages up-regulate Bcl-3 expression and interaction with p52 upon human cytomegalovirus infection [61]. Subsequently, the Bcl-3/p52 complex binds to the major immediate-early promoter (MIEP) of human cytomegalovirus and was suggested to regulate MIEP expression [61].

\subsubsection{IK $\mathrm{B} \zeta$ in macrophages}

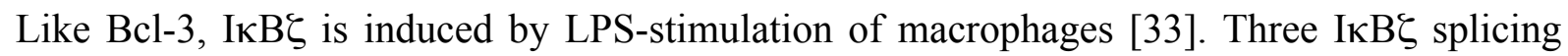
variants, namely $\operatorname{I\kappa B} \zeta(\mathrm{S})$ also called INAP, I $\mathrm{I} \mathrm{B} \zeta(\mathrm{L})$ and $\mathrm{I} \kappa \mathrm{B} \zeta(\mathrm{D})$ have been described 


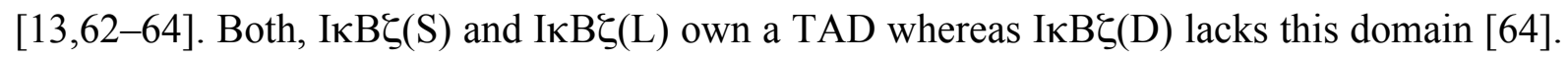

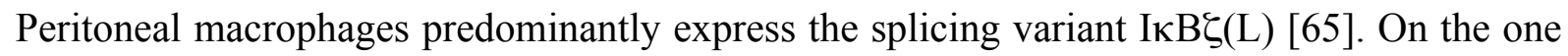

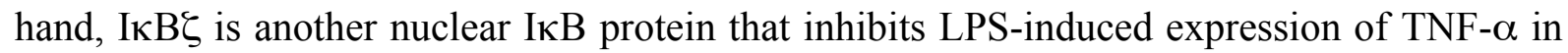
macrophages [64]. On the other hand, p50-bound $\mathrm{I} \kappa \mathrm{B} \zeta$ enhances the expression of IL-6 via association to its promoter, in contrast to Bcl-3, which does not regulate IL-6 [34,64,66,67]. The binding sites of NF- $\mathrm{KB}$ and $\mathrm{cEBP} \beta$ in the $I l 6$ promoter were suggested to be essential for

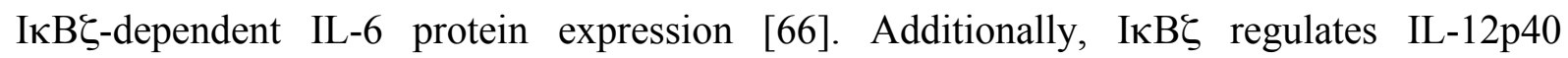

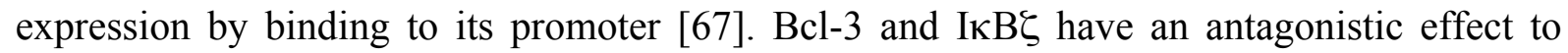
CCL2 expression in macrophages. While Bcl-3 inhibits the expression of CCL2, IкB $\zeta$ promotes the expression of this chemokine by interaction with its promoter and induction of transcription $[57,68]$. Furthermore, the LPS-induced mRNA expression of GM-CSF and G-

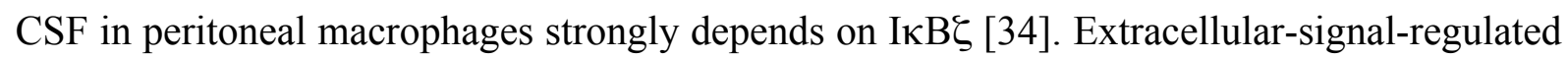
kinase (ERK) inhibition in macrophages, did not affect the expression of $\mathrm{I \kappa B} \zeta$, indicating that

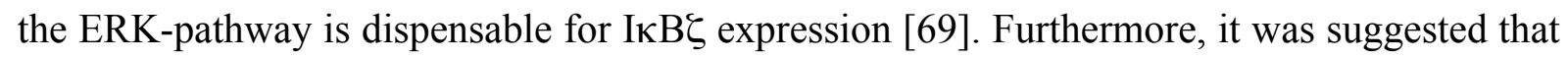
$\mathrm{I \kappa B} \zeta$ is an essential regulator for the tri-methylation of $\mathrm{H} 3 \mathrm{~K} 4$ (Histone 3 Lysine 4), which is an epigenetic marker of transcriptionally active chromatin [67].

\subsubsection{I $\mathrm{K} \mathrm{B}_{\mathrm{NS}}$ in macrophages}

$\mathrm{I}_{\mathrm{N}} \mathrm{B}_{\mathrm{NS}}$ was shown to be expressed by macrophages of the colonic lamina propria and the peritoneum. Iא $\mathrm{B}_{\mathrm{NS}}$ is an essential negative regulator of the MyD88-dependent cytokines IL-6,

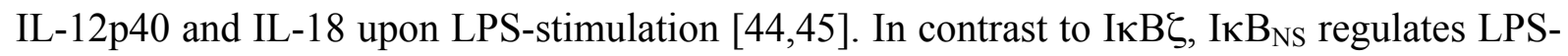
induced expression of IL-6 and IL-12p40 in macrophages in a negative manner while it is dispensable for TNF- $\alpha$ expression in macrophages [44,45]. These effects are mediated by the interaction of a $\mathrm{p} 50 / \mathrm{I}_{\mathrm{K}} \mathrm{B}_{\mathrm{NS}}$ complex with the IL- 6 but not the TNF- $\alpha$ promoter [44]. The 
analysis of basal protein expression of peritoneal and lamina propria macrophages indicated $\mathrm{I} \mathrm{B}_{\mathrm{NS}^{-}}$as well as Bcl-3-dependent suppression of inflammatory responses in the intestine. Whereas peritoneal macrophages do not express these two nuclear IкB proteins before LPSstimulation, lamina propria macrophages exhibit basal expression, which might suppress excessive intestinal inflammatory cytokines expression [44]. In a model of septic shock, I $\mathrm{B}_{\mathrm{NS}}-$ deficient animals showed significantly increased expression of IL-6 and IL-12p40, resulting in exacerbated lethality, similarly to Bcl-3-deficient mice [45]. Further investigations demonstrated the dispensability of $\mathrm{I}_{\mathrm{N}} \mathrm{B}_{\mathrm{NS}}$ for the movement of macrophages toward injured arteries [70].

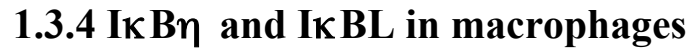

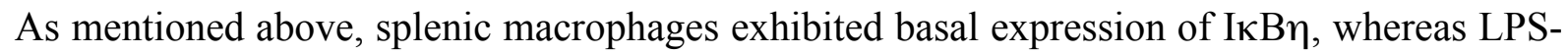

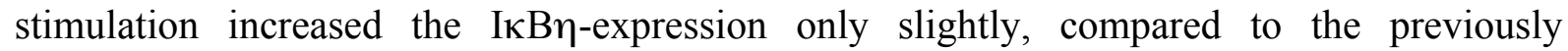

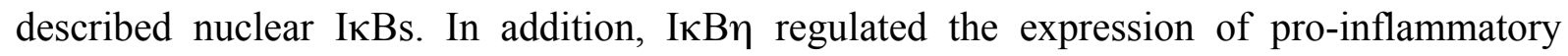
cytokines, similarly to $\mathrm{Bcl}-3, \mathrm{I} \kappa \mathrm{B} \zeta$ and $\mathrm{I} \kappa \mathrm{B}_{\mathrm{NS}}$. Moreover, the expression of LPS-induced IL-

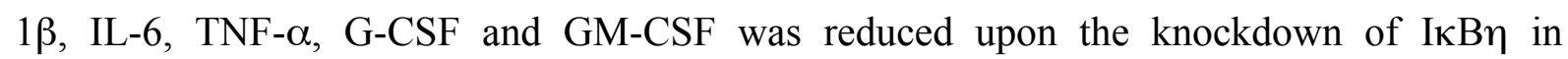
macrophage cell lines [15].

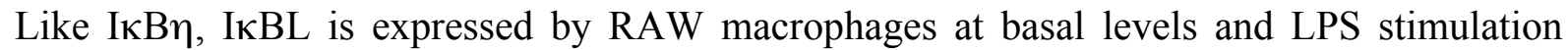
slightly increased this expression. Furthermore, IкBL exhibited an inhibitory effect towards LPS-induced expression of IL- 6 and TNF- $\alpha$ but did not regulate the expression of IL-1 $\beta$ in macrophages [52]. 


\subsection{Atypical IкB proteins in other innate immune cells}

Besides macrophages, more innate immune cells respond to infection in an early immune phase. In this section we sum up the knowledge of nuclear IкBs in dendritic cells (DC), mast cells, neutrophils and natural killer cells (NK).

\subsubsection{Bcl-3 in innate immune cells}

Bcl-3 affects phagocytes, DCs and neutrophils. Similar to macrophages, LPS was shown to induce the expression of Bcl-3 in DCs [71]. Bcl-3-deficient mice do not have GC and their follicular DCs do not form the typical clusters observed in wildtype GC. Furthermore, follicular DCs are reduced in number whereas the numbers of myeloid DCs are increased but disorderly distributed [28,29]. In bone marrow-derived DCs LPS-induced Bcl-3 suppresses the expression of IL-23p19, an essential cytokine in $\mathrm{T}$ helper $17\left(\mathrm{~T}_{\mathrm{H}} 17\right)$ cell expansion and survival $[31,72]$. Further analysis of bone marrow-derived DCs revealed that Bcl-3 inhibits the LPS-induced mRNA expression of IL-1 $\beta$, IL- 6 and TNF- $\alpha$ as observed in macrophages [57]. In contrast, an analysis of cytokine secretion by Bcl-3-deficient bone marrow-derived DCs showed unaltered secretion of IL-6, IL-10, IL-12p70 and TNF- $\alpha$ [73]. Moreover, conditional CD11 ${ }^{+}$-specific (Bcl-3- $\left.\Delta \mathrm{DC}\right)$ or conventional Bcl-3 knockout mice were infected with $T$. gondii and cytokine secretion was measured. IL-12p40 and IL-12p70 expression was unaltered three days after infection but, was reduced after a week [30]. In addition, Bcl-3$\Delta \mathrm{DC}$ as well as Bcl-3-deficient mice were highly susceptible to $T$. gondii infection. In this regard, Bcl-3 was suggested to be dispensable in the early innate response by DCs but essential in DC-dependent activation and priming of the adaptive $\mathrm{T}$ cell response [30]. Furthermore, survival, maturation and expansion of DCs was supported by Bcl-3 [73]. Upon Klebsiella pneumoniae infection of Bcl-3-deficient mice an increased number of neutrophils was recruited to the infected lungs, presumably due to an increased expression of the 
neutrophil-attracting chemokines CXCL1 and CXCL2. Nevertheless, Bcl-3-defective mice were much more susceptible to $K$. pneumoniae infection. While the bacterial uptake by neutrophils did not depend on Bcl-3 but inhibited intracellular killing [59]. Bcl-3 expression in mast cells was induced by IL-4 as well as IL-9 stimulation and presumably depends on Jak/STAT signalling [20]. In T. gondii infection Bcl-3-deficient NK cells showed a normal expression of IFN- $\gamma$ at least in the early immune response [30]. Besides, preservation of cytotoxic activity of Bcl-3-defective NK cells was observed in T. gondii infection [28].

\subsubsection{IK B $\zeta$ in innate immune cells}

I $\mathrm{B} \zeta$-deficient mice exhibited reduced infiltration of monocytes in a model of peritonitis, which was suggested to arise from reduced expression of the monocyte-chemotactic CCL2 [68]. IL-1 $\beta$ or TLR-signalling in murine and human monocytes induces the expression of

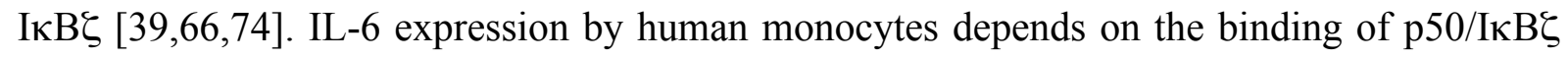
to its promoter. Furthermore, the expression of $\mathrm{I} \kappa \mathrm{B} \zeta$ was higher in monocytes compared to monocyte-derived macrophages, which was in turn reflected in lower IL-6 expression in macrophages compared to monocytes [66]. Furthermore, IкB $\zeta$-induced IL-6 expression not

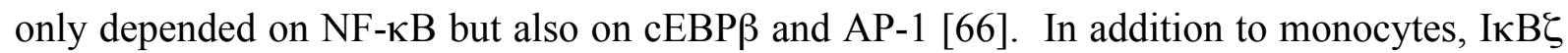
was expressed in DCs and LPS-induced IL-6 expression was reduced in IאBל-defective

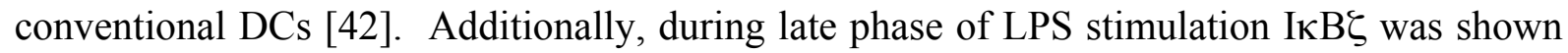
to mediate the targeting of the Il6-promoter by the ten-eleven translocation-2 protein und thus the repression of the IL- 6 gene. [75]. In DCs, $\beta$-glucan enhanced the expression of IL- $1 \beta$. Both IL-1 $\beta$ as well as $\beta$-glucan activated human DCs and were crucial in maintenance of high

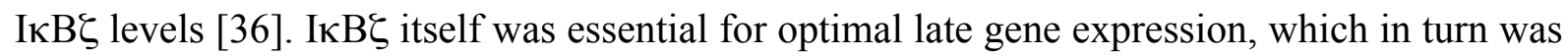
necessary for DC migration, adhesion, production of antimicrobials and $\mathrm{T}_{\mathrm{H}} 17$-polarising 


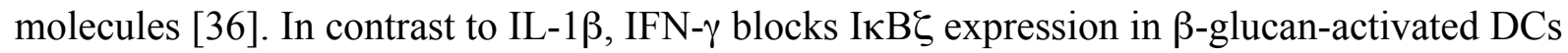
and consequently the $\mathrm{T}_{\mathrm{H}} 17$-priming cytokines IL-6 and IL23 [36].

The expression of IкB $\zeta$ by NK cells was induced upon activation with IL-12 plus IL-18. Furthermore, I $\mathrm{I} \mathrm{B} \zeta$ itself was essential for IL-12/IL-18-induced gene expression and NK cell cytotoxic activity, but not NK cell development. In that respect, IL-12 plus IL-18-induced

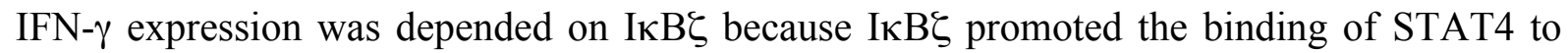
conserved non-coding elements of Ifng promoter [38]. Additionally, I $\kappa \mathrm{B} \zeta$ bound to the promoter of INF- $\gamma$ via association to $\mathrm{p} 50 / \mathrm{p} 65$ [74].

\subsubsection{IK $\mathrm{B}_{\mathrm{NS}}$ in innate immune cells}

$\mathrm{I} \mathrm{B}_{\mathrm{NS}}$ is dispensable for surface expression of MHC-II or the co-stimulatory ligand CD86 in LPS stimulated bone marrow-derived DCs [45]. Additionally, IкB $\mathrm{B}_{\mathrm{NS}}$ was not involved in TNF- $\alpha$ and IL-10 production, but is crucial for IL-6, IL-12p40 and IL-12p70 expression in bone marrow-derived DCs [45]. Compared to conventional DCs, regulatory DCs produced reduced levels of pro-inflammatory cytokines but increased levels of IL-10, thereby reducing serum levels of pro-inflammatory cytokines that are produced by LPS-stimulated macrophages. Furthermore, regulatory DCs showed increased expression of $\mathrm{I}_{\mathrm{B}} \mathrm{B}_{\mathrm{NS}}$ as well as Bcl-3 compared to conventional DCs, whereas $\mathrm{I} \mathrm{B}_{\mathrm{NS}}$ was expressed 2-fold higher than Bcl-3 [76]. To which extent both $\mathrm{I} \mathrm{B}_{\mathrm{NS}}$ and $\mathrm{Bcl}-3$ are involved in the suppression of proinflammatory cytokines and the induction of IL-10 will be a subject of future studies.

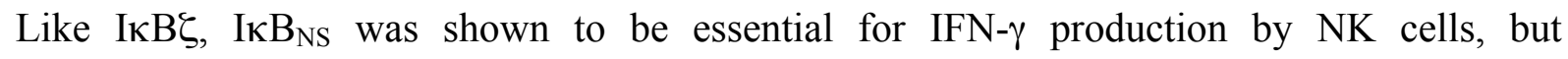
dispensable for their cytotoxic activity. Furthermore, I $\mathrm{B}_{\mathrm{NS}}$-deficient mice do not suffer from defective NK cell differentiation [46]. 


\subsection{4 $4 \mathrm{I \kappa} B \eta$ and IKBL in innate immune cells}

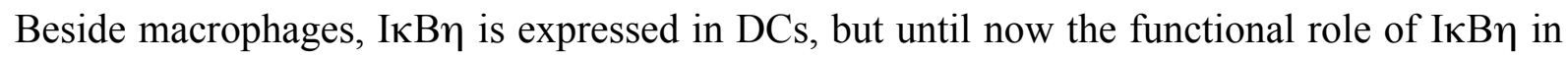
DCs is not known [15]. In transgenic mice human IкBL was expressed in DCs inhibiting the expression of co-stimulators and the production of cytokines (IL-2, IL-6 and TNF- $\alpha$ ) upon LPS-stimulation. In line with these observations, human IאBL expressing DCs are less efficient to induce $\mathrm{T}$ cell differentiation [77].

\subsection{Atypical IK B proteins in lymphocytes of the adaptive immune system}

The adaptive immune response is essential for specifically combating pathogenic invaders and for generating memory for a faster immune reaction to a subsequent second infection. Band T-lymphocytes facilitate the defence against pathogens, which overcome the first barriers of the immune system and their precise regulation is crucial to circumvent autoimmunity. The function of nuclear IкB proteins in T cells shown in this section is summarized in Table 1 and Figure 1B.

\subsubsection{Bcl-3 in adaptive immunity}

Bcl-3 was shown to be essential in the development of a proper architecture of secondary lymphoid organs as well as effective adaptive immunity. The splenic architecture of Bcl-3deficient mice is defective, with absence of germinal centres and distinct B cell follicular areas $[27,28]$. Furthermore, intestinal PP show structural changes and are reduced in number as well as in size $[27,29]$. High Bcl-3 expression was found in B cell follicular areas of the spleen [60]. Moreover, Bcl-3-deficient mice show a reduction in the frequencies and absolute numbers of follicular (FO) B cells $[29,78]$. The disruption of the microarchitecture of PP and spleen is reflected in defective adaptive immune responses, since Bcl-3-deficient mice are more susceptible to infections with L. monocytogenes, S. pneumoniae, T. gondii and influenza 
$[27,28]$. Bcl-3 is dispensable for immunoglobulin production in the steady state and upon infection. However, generation of pathogen-specific antibodies was highly diminished in the absence of Bcl-3 [27,28]. Furthermore, Bcl-3 is essential in $\mathrm{T}$ cell-dependent antibody responses, since the GC reaction upon immunisation with the model antigen 2,4,6Trinitrophenyl-keyhole limpet hemocyanin (TNP-KLH) immunisation is impaired in Bcl-3deficient animals [28]. In contrast to the reduced number of FO B cells, Bcl-3-deficient mice exhibit an increase of marginal zone (MZ) B cells, whereas a B cell-specific overexpression of Bcl-3 induces a lack of MZ B cells in mice $[78,79]$. In both, FO and MZ B cells surface expression levels of MHC-II, CD40, CD54, CD69, CD86 as well as the $\alpha$ L-subunit of the $\beta 2$ integrin LFA-1 were increased upon loss of Bcl-3. Elevated expression of the LFA-1 subunit was suggested to increase retention of MZ B cells in Bcl-3-deficient marginal zones [78]. Although the proliferation of Bcl-3-deficient B cells is elevated upon LPS-stimulation compared to wildtype cells, the proliferation of FO B cell is reduced upon anti-IgM treatment $[57,78]$. An enhanced number of Bcl-3-deficient FO B cells is positive for activated caspase3, suggesting that Bcl-3 supports FO B cell survival [78]. In contrast to B cells, the frequency of splenic T cells was almost unaltered in Bcl-3-deficient mice and PP contained more CD8 ${ }^{+}$ T cells $[29,80]$. In T cells, Bcl-3 acts as a survival signal but is dispensable for the regulation of proliferation, cell cycle and IL-2 expression [71,80-82]. Bcl-3 expression was shown to be induced by IL-4, with AP-1 and AP-1-like proteins being essential for IL-4-induced Bcl-3 promoter activity [21]. As reported for mast cells, IL-9 stimulation also induces Bcl-3 expression in T cells in a Jak/STAT-dependent manner [20]. In $\mathrm{CD}^{+} \mathrm{T}$ cells, Bcl-3 is crucial for maximal IFN- $\gamma$ production upon a second antigen treatment, whereas it is dispensable for IFN- $\gamma$ production in $\mathrm{CD}^{+}$cell [83]. Furthermore, $\mathrm{CD}^{+} \mathrm{T}$ cells require three signals for efficient clonal expansion, full activation and memory establishment. Besides antigen recognition and co-stimulation, IL-12 is an essential signal in $\mathrm{CD} 8^{+} \mathrm{T}$ cells and IL-12 
promoted $\mathrm{CD}^{+} \mathrm{T}$ cell survival in a Bcl-3-specific manner $[25,83]$. Bcl-3 was shown to support $\mathrm{T}_{\mathrm{H}} 2$ cells, since p50/Bcl-3 complex binds and transactivates the $\mathrm{T}_{\mathrm{H}} 2$ master transcription factor GATA3 and thus promotes $\mathrm{T}_{\mathrm{H}} 2$ differentiation [84]. Bcl-3-deficient mice were resistant to $\mathrm{T}$ cell transfer model of colitis and EAE induction. This resistance was mediated by reduction of IFN- $\gamma^{+} \mathrm{T}_{\mathrm{H}} 1$ cells but an increase of IL-17 $7^{+}$cells [85]. Nevertheless, Bcl-3 is not important for $\mathrm{T}_{\mathrm{H}} 1$ differentiation and expression of the master transcription factor T-bet [84]. Furthermore, Bcl-3-deficient $T_{H} 1$ cells proliferated normally, although more $T_{H} 1$ cells convert to $T_{H} 17-1$ ike cells. Thus, Bcl-3 was suggested to promote the $T_{H} 1$ phenotype [85]. In contrast to Bcl-3-defective NK cells having normal cytotoxic activity, cytotoxic T lymphocyte activity was reduced in $T$. gondii infected Bcl-3-deficient mice [28]. In summary, Bcl-3 regulates differentiation, survival and effector functions of various $\mathrm{B}$ cell and $\mathrm{T}$ cell subsets.

\subsubsection{IкB $\zeta$ in adaptive immunity}

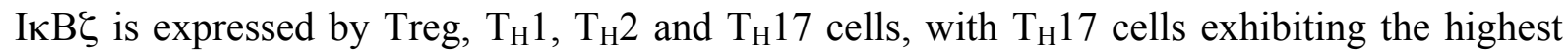
expression level [42]. $T_{H} 17$ cells mainly express $\operatorname{I\kappa B} \xi(L)$ and low levels of $\operatorname{I\kappa B} \xi(S)$, but not

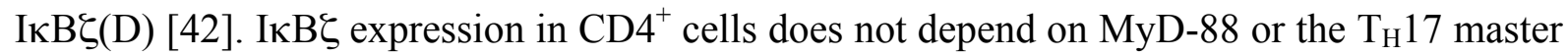
transcription factor ROR $\gamma \mathrm{t}$, but is regulated by STAT3 [42]. Additionally, $\mathrm{CD}^{+} \mathrm{T}$ cell proliferation, the in vitro differentiation of $\mathrm{T}_{\mathrm{H}} 1$ and $\mathrm{T}_{\mathrm{H}} 2$ cells and the in vivo development of

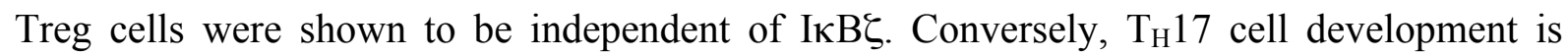
regulated by $\mathrm{I} \kappa \mathrm{B} \zeta[42]$. At this point it has to be mentioned that the two cytokines that are essential in $\mathrm{T}_{\mathrm{H}} 17$ cell differentiation, IL- 6 and TGF- $\beta$, induce the expression of IкB $\zeta$ [42]. Furthermore, I $\mathrm{I} B \xi$-deficient cells exhibited a reduced mRNA expression of the $\mathrm{T}_{\mathrm{H}} 17$-related genes $I l 17 a, I l 21, I l 22$ and $I l 23 r$ [42]. IKB $\zeta$ was recruited to the promoter or enhancer region of these genes. In this respect, in $\mathrm{T}_{\mathrm{H}} 17$-primed cells $\mathrm{I} \kappa \mathrm{B} \zeta, \mathrm{ROR} \gamma \mathrm{t}$ as well as $\mathrm{ROR} \alpha$ 
cooperated in IL-17A expression. IKBל binds to the promoter of IL-17A in a ROR $\gamma$ tdependent and ROR $\alpha$-dependent manner and was suggested to enhance the binding of transcriptional co-activators to drive $I l 17 a$ expression [42]. Thus, ІкB $\zeta$-deficient mice exhibited an almost absent $T_{H} 17$ response while the $T_{H} 1$ response was not affected in EAE [42]. Additionally, EAE was induced after adoptive transfer of $\mathrm{CD}^{+}$cells into RAG2deficient mice and animals reconstituted with $I \kappa B \zeta$-deficient cells were resistant, revealing a

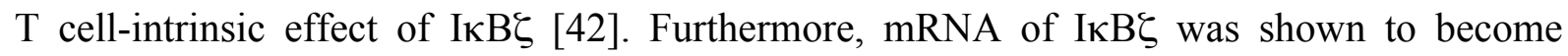
degraded by the RNase Regnase-1 (also termed as MCPIP1), which impaired the expression

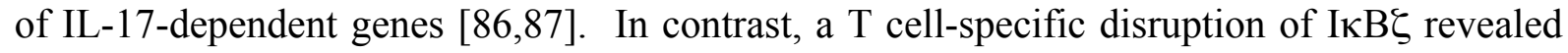
an inhibitory effect of $\mathrm{I} \kappa \mathrm{B} \zeta$ in $\mathrm{T}_{\mathrm{H}} 1$ and Treg cell differentiation. Hence, $\mathrm{I} \kappa \mathrm{B} \zeta^{\mathrm{S}}{ }^{\mathrm{Lck}}$ mice exhibited an increased expression of $\mathrm{IFN}^{+}$and $\mathrm{FoxP}^{+}$cells in the periphery [88]. It was suggested that $\mathrm{I} \kappa \mathrm{B} \zeta$ negatively regulates the activity of the IFN- $\gamma$ promoter [88]. Furthermore,

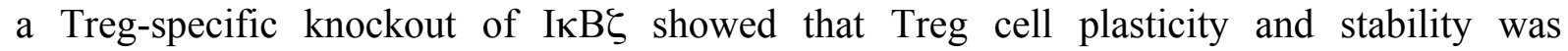
autonomous from $\mathrm{I} \kappa \mathrm{B} \zeta$, whereas their immune-regulatory function depended on $\mathrm{I} \kappa \mathrm{B} \zeta$ [88]. Moreover, analysis of the effect of IкB $\zeta$ in Treg differentiation revealed the inhibition of the FoxP3 promoter by $\mathrm{I} \kappa \mathrm{B} \zeta$ [37]. Thus, speculations arose, whether I $\mathrm{I} \mathrm{B} \zeta$ is essential in maintaining $\mathrm{T}_{\mathrm{H}}$ cell homeostasis $[37,88]$.

The expression of $\mathrm{I} \kappa \mathrm{B} \zeta$ is induced upon $\mathrm{B}$ cell stimulation via the $\mathrm{B}$ cell receptor (BCR), TLR7 or TLR9, whereat the BCR and TLRs act synergistically $[35,89]$. Furthermore, IאB\} signalling in B cells is essential for TLR-induced but not BCR-induced Il10 and Ctla4 gene induction as well as B cell proliferation. In contrast, TLR- but not BCR-induced secretion of TNF- $\alpha$ as well as the up-regulation of CD86 is inhibited by IкB $\zeta$ [35]. In addition, B cell

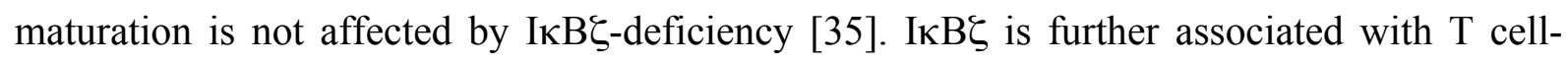
independent type 1 humoral responses, given that $\operatorname{IgM}$ and $\operatorname{IgG} 3$ levels were reduced upon immunisation with TNP-LPS, but not upon TNP-Ficoll (type 2) immunisation. This defect in 
T cell-independent type 1 humoral responses of B cells was hypothesised to arise from defective differentiation to plasma cells and class switch recombination after TLR signalling $[35]$.

\subsubsection{I $\kappa B_{N S}$ in adaptive immunity}

I $\kappa B_{N S}$ is expressed by $T$ cell subsets such as $T_{H} 1, T_{H} 17$ and Treg precursor cells $[43,46,49]$. Its expression is upregulated in the thymus by signals triggering negative selection, as well as the TCR in the periphery $[14,43] . \mathrm{CD}^{+}$and $\mathrm{CD} 8^{+} \mathrm{T}$ cells and thymocytes deficient for $\mathrm{IKB}_{\mathrm{NS}}$ are defective in proliferation upon TCR stimulation, but were shown to proliferate like wildtype cells after the addition of IL-2 or IL-7 $[45,46]$. IкB $\mathrm{B}_{\mathrm{NS}}$ regulates the expression of IL2 in lymphocytes and LN-derived $\mathrm{CD}^{+} \mathrm{T}$ cells. The regulation of IL-2 by $\mathrm{I}_{\mathrm{N}} \mathrm{B}_{\mathrm{NS}}$ is mediated via the NF-KB binding site within the IL-2 gene locus. Furthermore, IFN $\gamma$ production by Iא $\mathrm{B}_{\mathrm{NS}}$-deficient lymphocytes and $\mathrm{LN}$-derived $\mathrm{CD} 8^{+} \mathrm{T}$ cells was reduced [46]. Nevertheless, the function of $\mathrm{I}_{\kappa} \mathrm{B}_{\mathrm{NS}}$ in $\mathrm{T}_{\mathrm{H}} 1$ differentiation is far from being clear. In experimental models of colitis, either induced by the chemical compound dextran sodium sulphate (DSS), which disrupts the epithelial barrier, or by transfer of naïve $\mathrm{T}$ cells into lymphopenic mice, increased expression of IFN $\gamma$ was detected in splenic $\mathrm{CD}^{+} \mathrm{T}$ cells (DSS colitis) or colon of $\mathrm{I} \mathrm{B}_{\mathrm{NS}^{-}}$ deficient $\mathrm{T}$ cell recipients (transfer colitis) $[43,45]$. Furthermore, after transfer of $\mathrm{I}_{\mathrm{K}} \mathrm{B}_{\mathrm{NS}^{-}}$ deficient $\mathrm{T}$ cell to RAG1-defective mice, recipient mice showed at least a mild increase of IFN $\gamma^{+} \mathrm{CD}^{+} \mathrm{T}$ cells $[43,49]$. In contrast, induction of EAE in I $\mathrm{BB}_{\mathrm{NS}}-$ defective mice did not alter the $\mathrm{T}_{\mathrm{H}} 1$ cell subset [50]. Additionally, Citrobacter rodentium infection of $\mathrm{I}_{\mathrm{K}} \mathrm{B}_{\mathrm{NS}}{ }^{-}$ deficient mice induced a reduction of IFN $\gamma^{+} \mathrm{CD} 4^{+} \mathrm{T}$ cells in the spleen but no differences were detectable in the colon [49]. However, efficient in vitro polarisation of IFN $\gamma^{+} \mathrm{T}$ cells from naïve $\mathrm{T}$ cells and proliferation of $\mathrm{T}_{\mathrm{H}} 1$-polarised cells depended on $\mathrm{I}_{\mathrm{K}} \mathrm{B}_{\mathrm{NS}}$ [49]. Besides $\mathrm{T}_{\mathrm{H}} 1$ cells, in vitro and in vivo $\mathrm{T}_{\mathrm{H}} 17$ polarisation and proliferation depended on $\mathrm{I} \mathrm{B}_{\mathrm{NS}}$. In 
Citrobacter rodentium infection and EAE, as well as colitis induction the number of IL-1 $7^{+} \mathrm{T}$ cells was severely diminished upon the loss of $\operatorname{IKB}_{\mathrm{NS}}[49,50]$. The expression of several cytokines was dependent on $\mathrm{I}_{\mathrm{K}} \mathrm{B}_{\mathrm{NS}}$, since IL-10, IL-17A, IL-17F and GM-CSF expression was impaired in $\mathrm{I}_{\mathrm{N}} \mathrm{B}_{\mathrm{NS}}$-deficient $\mathrm{T}_{\mathrm{H}} 17$ cells $[49,50]$. Furthermore, $\mathrm{CD} 4^{+} \mathrm{I}_{\mathrm{B}} \mathrm{B}_{\mathrm{NS}}$-deficient cells were defective in $\mathrm{T}_{\mathrm{H}} 17$-related ROR $\gamma \mathrm{t}$ and CCR6 expression, which, at least in part, may explain their defect in cytokine secretion. However, direct regulation of the $1117 a$ gene locus by $I \kappa B_{N S}$ was excluded [50]. In contrast, a chromatin immunoprecipitation showed the binding of $I \kappa B_{N S}$ to the $I l 10$ gene locus, hence IL-10 is directly regulated by I $_{\text {N }} \mathrm{B}_{\mathrm{NS}}$ [49]. Since the $\mathrm{I} \kappa \mathrm{B}_{\mathrm{NS}}$ protein itself does not contain a DNA-binding domain, it is currently unclear via which transcription factor $I \kappa B_{N S}$ is recruited to the to the $I l 10$ locus. Future experiments have

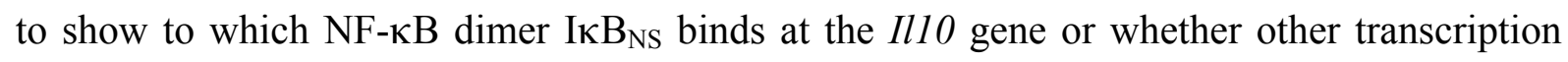
factors mediate $\mathrm{I}_{\mathrm{B}} \mathrm{B}_{\mathrm{NS}}$ recruitment.

IкBNS-deficient mice exhibit a roughly 50\% reduction in regulatory $\mathrm{T}$ cells [43]. Surprisingly, apoptosis was not affected by $\mathrm{I}_{\mathrm{K}} \mathrm{B}_{\mathrm{NS}}$ [43]. Furthermore, in contrast to the reduced proliferation of $\mathrm{I}_{\mathrm{N}} \mathrm{B}_{\mathrm{NS}}$-deficient $\mathrm{T}_{\mathrm{H}} 1$ and $\mathrm{T}_{\mathrm{H}} 17$ cells, peripheral Treg cells from I $\kappa B_{N S}$-deficient mice exhibited increased proliferation in the steady-state [43]. Instead, the reduced Treg cell numbers were due to a defect in Treg development, since I $\kappa \mathrm{B}_{\mathrm{NS}}$ mediated the transition of Treg precursors into mature Treg cells by driving the expression of FoxP3 [43]. In this regard, $\mathrm{I}_{\mathrm{K}} \mathrm{B}_{\mathrm{NS}}$ binds together with $\mathrm{p} 50$ and c-Rel to the promoter and the conserved non-coding sequence-3 within the FoxP3 gene locus [43]. On the other hand, after the induction of FoxP3 $\mathrm{I}_{\mathrm{N}} \mathrm{B}_{\mathrm{NS}}$ gene expression is suppressed by the transcription factor FoxP3 itself $[43,90]$. Accordingly, $\mathrm{I}_{\mathrm{K}} \mathrm{B}_{\mathrm{NS}}$ is dispensable for the regulation of Treg cell functionality, since $\mathrm{I} \kappa \mathrm{B}_{\mathrm{NS}}$-deficient Treg cells are as efficient in suppression of conventional cells as their wildtype counterparts [43]. 
Besides $\mathrm{T}$ cells, $\mathrm{I}_{\mathrm{B}} \mathrm{B}_{\mathrm{NS}}$ is an essential regulator of $\mathrm{B}$ cell development and function. Mice deficient for I $\kappa B_{\mathrm{NS}}$ are defective in the development of B1 B cells and MZ B cells and the differentiation to plasma cells. Furthermore, the humoral immune response is deregulated. Although I $\mathrm{I}_{\mathrm{NS}}$-deficient B cells exhibit increased surface levels of $\operatorname{IgM}$, the serum levels of some immunoglobulins (IgM, IgG3) are reduced [47,48]. Moreover, the $\operatorname{I\kappa B}_{\mathrm{NS}}$-deficient animals were further impaired to mounting a $\mathrm{T}$ cell-dependent humoral immune response, as well as in generating antigen-specific immunoglobulins and exhibit a defective IgG3 class switch [47]. Finally, the proliferation of $\mathrm{I}_{\mathrm{K}} \mathrm{B}_{\mathrm{NS}}$-deficient B cells upon LPS or anti-CD40 stimulation was decreased, while was not affected upon BCR-stimulation [47,48].

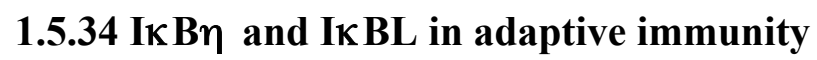

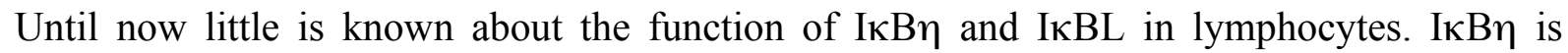
known to be expressed in T and B cells [15]. IкBL was shown to be expressed in $\mathrm{T}$ cells in rheumatoid synovial tissue [54]. Overexpression of IאBL in T cells uncovered a suppressor

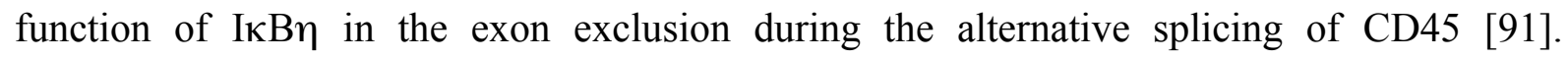
Additionally, transgenic expression of human IאBL increased the proliferation and IL-2 expression of murine $\mathrm{T}$ cells [77]. Clearly, further studies are necessary to identify distinct

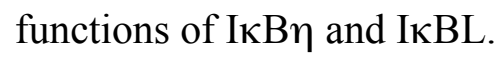

\subsection{Conclusions}

The discovery of the reciprocal effect of the transcription factor NF- $\mathrm{KB}$ and its regulators, the IкB-proteins, is an essential step forward towards understanding gene regulation during infections and inflammatory processes. Previous studies revealed that nuclear IкB-proteins are essential for survival, clearance of infections and for protection from autoimmunity. Nuclear IкB-proteins regulate differentiation, maturation and activation of immune cells and 
thus, expression of their surface markers, cytokines, chemokines and other effector proteins (like immunoglobulins). In short, the whole immune reaction is guided by the regulation of

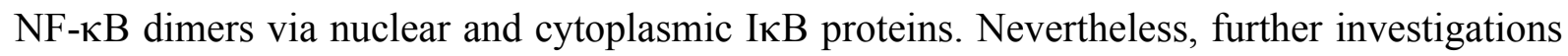
are necessary to illuminate the specific regulation of a particular disease by nuclear IкBs. Consequently, by gaining more insights into the biology of nuclear IкBs we might develop novel strategies to treat infections or autoimmune diseases much better in the future. An initial step is the work of Collins and colleagues who designed a peptide mimicking the functional activity of the ANK1 of Bcl-3 (amino acid 144- 158) [43]. To this end, they fused the Bcl-3-derived peptide with the HIV-tat cargo carrying sequence and the resulting peptide was named BDP2. The BDP2 peptide was able to inhibit TLR-induced cytokine expression in vitro, as well as strongly reduced carrageenan-induced oedema formation and production of the cytokines IL- 6 and TNF- $\alpha$ [43]. Thus, nuclear IкB proteins are promising targets for the development of new improved drugs for the therapy of autoimmunity and infections, however their pharmacological relevance needs to be revealed. 


\section{Acknowledgements}

K. K.-D. was supported by the President's Initiative and Networking Fund of the Helmholtz Association of German Research Centers (HGF) under contract number VH-GS-202. This work was supported by grants from the the Deutsche Forschungsgemeinschaft SFB854, project B12 to S.K. and B.S., as well as SFB 854, project A23N, SCHM1586/6-1 and the Fritz Thyssen Stiftung to I.S.. 


\section{References}

[1] Sen R, Baltimore D. Multiple nuclear factors interact with the immunoglobulin enhancer sequences. Cell 1986;46:705-16.

[2] Gerondakis S, Fulford TS, Messina NL, Grumont RJ. NF- $\kappa B$ control of $\mathrm{T}$ cell development. Nat Immunol 2014;15:15-25. doi:10.1038/ni.2785.

[3] Hayden MS, Ghosh S. NF-kappaB, the first quarter-century: remarkable progress and outstanding questions. Genes Dev 2012;26:203-34. doi:26/3/203 [pii] 10.1101/gad.183434.111.

[4] Ghosh S, Hayden MS. Celebrating 25 years of NF-кB research. Immunol Rev 2012;246:5-13. doi:10.1111/j.1600-065X.2012.01111.x.

[5] Hinz M, Arslan SÇ, Scheidereit C. It takes two to tango: IкBs, the multifunctional partners of NF-кB. Immunol Rev 2012;246:59-76. doi:10.1111/j.1600065X.2012.01102.x.

[6] Kanarek N, Ben-Neriah Y. Regulation of NF- $\kappa B$ by ubiquitination and degradation of the IאBs. Immunol Rev 2012;246:77-94. doi:10.1111/j.1600-065X.2012.01098.x.

[7] Siebenlist U, Brown K, Claudio E. Control of lymphocyte development by nuclear factor-kappaB. Nat Rev Immunol 2005;5:435-45. doi:10.1038/nri1629.

[8] Kerr LD, Duckett CS, Wamsley P, Zhang Q, Chiao P, Nabel G, et al. The protooncogene bcl-3 encodes an I kappa B protein. Genes Dev 1992;6:2352-63. doi:10.1101/gad.6.12a.2352.

[9] Franzoso G, Bours V, Park S, Tomita-Yamaguchi M, Kelly K, Siebenlist U. The candidate oncoprotein Bcl-3 is an antagonist of p50/NF-kappa B-mediated inhibition. Nature 1992;359:339-42. doi:10.1038/359339a0. 
[10] Hatada EN, Nieters A, Wulczyn FG, Naumann M, Meyer R, Nucifora G, et al. The ankyrin repeat domains of the NF-kappa B precursor p105 and the protooncogene bcl-3 act as specific inhibitors of NF-kappa B DNA binding. Proc Natl Acad Sci U S A 1992;89:2489-93.

[11] Wulczyn FG, Naumann M, Scheidereit C. Candidate proto-oncogene bcl-3 encodes a subunit-specific inhibitor of transcription factor NF-kappa B. Nature 1992;358:597-9. doi:10.1038/358597a0.

[12] Nolan GP, Fujita T, Bhatia K, Huppi C, Liou HC, Scott ML, et al. The bcl-3 protooncogene encodes a nuclear I kappa B-like molecule that preferentially interacts with NF-kappa B p50 and p52 in a phosphorylation-dependent manner. Mol Cell Biol 1993;13:3557-66. doi:10.1128/MCB.13.6.3557.Updated.

[13] Kitamura H, Kanehira K, Okita K, Morimatsu M, Saito M. MAIL, a novel nuclear I kappa B protein that potentiates LPS-induced IL-6 production. FEBS Lett 2000;485:53-6. doi:10.1016/S0014-5793(00)02185-2.

[14] Fiorini E, Schmitz I, Marissen WE, Osborn SL, Touma M, Sasada T, et al. Peptideinduced negative selection of thymocytes activates transcription of an NF-kappa B inhibitor. Mol Cell 2002;9:637-48.

[15] Yamauchi S, Ito H, Miyajima A. IkappaBeta, a nuclear IkappaB protein, positively regulates the NF-kappaB-mediated expression of proinflammatory cytokines. Proc Natl Acad Sci U S A 2010;107:11924-9. doi:10.1073/pnas.0913179107.

[16] Handel-Fernandez ME, Vincek V. Sequence analysis and expression of a mouse homolog of human IkappaBL gene. Biochim Biophys Acta 1999;1444:306-10.

[17] Ohno H, Takimoto G, McKeithan TW. The candidate proto-oncogene bcl-3 is related to genes implicated in cell lineage determination and cell cycle control. Cell 
1990;60:991-7.

[18] Bours V, Franzoso G, Azarenko V, Park S, Kanno T, Brown K, et al. The oncoprotein Bcl-3 directly transactivates through kappa B motifs via association with DNA-binding p50B homodimers. Cell 1993;72:729-39.

[19] Caamaño JH, Perez P, Lira S a, Bravo R. Constitutive expression of Bc1-3 in thymocytes increases the DNA binding of NF-kappaB1 (p50) homodimers in vivo. Mol Cell Biol 1996;16:1342-8.

[20] Richard M, Louahed J, Demoulin JB, Renauld JC. Interleukin-9 regulates NF-kappaB activity through BCL3 gene induction. Blood 1999;93:4318-27.

[21] Rebollo A, Dumoutier L, Renauld JC, Zaballos A, Ayllón V, Martínez-A C. Bcl-3 expression promotes cell survival following interleukin-4 deprivation and is controlled by AP1 and AP1-like transcription factors. Mol Cell Biol 2000;20:3407-16. doi:10.1128/MCB.20.10.3407-3416.2000.

[22] Wessells J, Baer M, Young H a., Claudio E, Brown K, Siebenlist U, et al. BCL-3 and NF-kappaB p50 attenuate lipopolysaccharide-induced inflammatory responses in macrophages. J Biol Chem 2004;279:49995-50003. doi:10.1074/jbc.M404246200.

[23] Elliott SF, Coon CI, Hays E, Stadheim T a., Vincenti MP. Bcl-3 is an interleukin-1responsive gene in chondrocytes and synovial fibroblasts that activates transcription of the matrix metalloproteinase 1 gene. Arthritis Rheum 2002;46:3230-9. doi:10.1002/art.10675.

[24] Kuwata H, Watanabe Y, Miyoshi H, Yamamoto M, Kaisho T, Takeda K, et al. IL-10inducible Bcl-3 negatively regulates LPS-induced TNF-alpha production in macrophages. Blood 2003;102:4123-9. doi:10.1182/blood-2003-04-1228.

[25] Valenzuela JO, Hammerbeck CD, Mescher MF. Cutting edge: Bcl-3 up-regulation by 
signal 3 cytokine (IL-12) prolongs survival of antigen-activated CD8 T cells. J Immunol 2005;174:600-4. doi:10.4049/jimmunol.174.2.600.

[26] Dagvadorj J, Naiki Y, Tumurkhuu G, Noman ASM, Iftekar-E-Khuda I, Koide N, et al. Interleukin (IL)-10 attenuates lipopolysaccharide-induced IL-6 production via inhibition of IkappaB-zeta activity by Bcl-3. Innate Immun 2009;15:217-24. doi:10.1177/1753425909103738.

[27] Schwarz EM, Krimpenfort P, Berns A, Verma IM. Immunological defects in mice with a targeted disruption in Bcl-3. Genes Dev 1997;11:187-97. doi:10.1101/gad.11.2.187.

[28] Franzoso G, Carlson L, Scharton-Kersten T, Shores EW, Epstein S, Grinberg A, et al. Critical roles for the Bcl-3 oncoprotein in $\mathrm{T}$ cell-mediated immunity, splenic microarchitecture, and germinal center reactions. Immunity 1997;6:479-90. doi:10.1016/S1074-7613(00)80291-5.

[29] Paxian S, Merkle H, Riemann M, Wilda M, Adler G, Hameister H, et al. Abnormal organogenesis of Peyer's patches in mice deficient for NF-kappaB1, NF-kappaB2, and Bcl-3. Gastroenterology 2002;122:1853-68. doi:10.1053/gast.2002.33651.

[30] Tassi I, Claudio E, Wang H, Tang W, Ha H, Saret S, et al. Adaptive immune-mediated host resistance to Toxoplasma gondii is governed by the NF- $\kappa \mathrm{B}$ regulator $\mathrm{Bcl}-3$ in dendritic cells. Eur J Immunol 2015;45:1972-9. doi:10.1002/eji.201445045.

[31] Ruan Q, Zheng S-J, Palmer S, Carmody RJ, Chen YH. Roles of Bcl-3 in the pathogenesis of murine type 1 diabetes. Diabetes 2010;59:2549-57. doi:10.2337/db100480.

[32] Yamazaki S, Muta T, Matsuo S, Takeshige K. Stimulus-specific induction of a novel nuclear factor-kappaB regulator, IkappaB-zeta, via Toll/Interleukin-1 receptor is mediated by mRNA stabilization. J Biol Chem 2005;280:1678-87. 
doi:10.1074/jbc.M409983200.

[33] Yamazaki S, Muta T, Takeshige K. A novel IkappaB protein, IkappaB-zeta, induced by proinflammatory stimuli, negatively regulates nuclear factor-kappaB in the nuclei. $\mathrm{J}$ Biol Chem 2001;276:27657-62. doi:10.1074/jbc.M103426200.

[34] Yamamoto M, Yamazaki S, Uematsu S, Sato S, Hemmi H, Hoshino K, et al. Regulation of Toll/IL-1-receptor-mediated gene expression by the inducible nuclear protein IkappaBzeta. Nature 2004;430:218-22. doi:10.1038/nature02738.

[35] Hanihara F, Takahashi Y, Okuma A, Ohba T, Muta T. Transcriptional and posttranscriptional regulation of I $\mathrm{I} B-\zeta$ upon engagement of the BCR, TLRs and Fc $\gamma \mathrm{R}$. Int Immunol 2013;25:531-44. doi:10.1093/intimm/dxt017.

[36] Cardone M, Dzutsev AK, Li H, Riteau N, Gerosa F, Shenderov K, et al. Interleukin-1 and interferon- $\gamma$ orchestrate $\beta$-glucan-activated human dendritic cell programming via

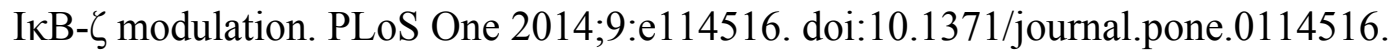

[37] MaruYama T. TGF- $\beta$-induced IкB- $\zeta$ controls Foxp3 gene expression. Biochem Biophys Res Commun 2015;464:586-9. doi:10.1016/j.bbrc.2015.07.013.

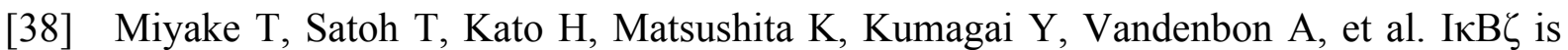
essential for natural killer cell activation in response to IL-12 and IL-18. Proc Natl Acad Sci U S A 2010;107:17680-5. doi:10.1073/pnas.1012977107.

[39] Totzke G, Essmann F, Pohlmann S, Lindenblatt C, Jänicke RU, Schulze-Osthoff K. A novel member of the IkappaB family, human IkappaB-zeta, inhibits transactivation of p65 and its DNA binding. J Biol Chem 2006;281:12645-54. doi:10.1074/jbc.M511956200.

[40] Shiina T, Konno A, Oonuma T, Kitamura H, Imaoka K, Takeda N, et al. Targeted disruption of MAIL, a nuclear IkappaB protein, leads to severe atopic dermatitis-like 
disease. J Biol Chem 2004;279:55493-8. doi:10.1074/jbc.M409770200.

[41] Ueta M, Hamuro J, Ueda E, Katoh N, Yamamoto M, Takeda K, et al. Stat6independent tissue inflammation occurs selectively on the ocular surface and perioral skin of IkappaBzeta-/- mice. Invest Ophthalmol Vis Sci 2008;49:3387-94. doi:10.1167/iovs.08-1691.

[42] Okamoto K, Iwai Y, Oh-Hora M, Yamamoto M, Morio T, Aoki K, et al. IkappaBzeta regulates $\mathrm{T}(\mathrm{H}) 17$ development by cooperating with ROR nuclear receptors. Nature 2010;464:1381-5. doi:10.1038/nature08922.

[43] Schuster M, Glauben R, Plaza-Sirvent C, Schreiber L, Annemann M, Floess S, et al. $\mathrm{I} \kappa \mathrm{B}(\mathrm{NS})$ protein mediates regulatory $\mathrm{T}$ cell development via induction of the Foxp3 transcription factor. Immunity 2012;37:998-1008. doi:10.1016/j.immuni.2012.08.023.

[44] Hirotani T, Lee PY, Kuwata H, Yamamoto M, Matsumoto M, Kawase I, et al. The nuclear IkappaB protein IkappaBNS selectively inhibits lipopolysaccharide-induced IL-6 production in macrophages of the colonic lamina propria. J Immunol $2005 ; 174: 3650-7$.

[45] Kuwata H, Matsumoto M, Atarashi K, Morishita H, Hirotani T, Koga R, et al. IkappaBNS inhibits induction of a subset of Toll-like receptor-dependent genes and limits inflammation. Immunity 2006;24:41-51. doi:10.1016/j.immuni.2005.11.004.

[46] Touma M, Antonini V, Kumar M, Osborn L, Bobenchik AM, Keskin DB, et al. Functional Role for IkappaBNS in T Cell Cytokine Regulation As Revealed by Targeted Gene Disruption. J Immunol 2007;179:1681-92.

[47] Touma M, Keskin DB, Shiroki F, Saito I, Koyasu S, Reinherz EL, et al. Impaired B cell development and function in the absence of IkappaBNS. J Immunol 2011;187:3942-52. doi:10.4049/jimmunol.1002109. 
[48] Arnold CN, Pirie E, Dosenovic P, McInerney GM, Xia Y, Wang N, et al. A forward genetic screen reveals roles for Nfkbid, Zeb1, and Ruvbl2 in humoral immunity. Proc Natl Acad Sci U S A 2012;109:12286-93. doi:10.1073/pnas.1209134109.

[49] Annemann M, Wang Z, Plaza-Sirvent C, Glauben R, Schuster M, Ewald Sander F, et al. IאBNS regulates murine Th17 differentiation during gut inflammation and infection. J Immunol 2015;194:2888-98. doi:10.4049/jimmunol.1401964.

[50] Kobayashi S, Hara A, Isagawa T, Manabe I, Takeda K, MaruYama T. The nuclear IkB family protein I $\mathrm{KBNS}$ influences the susceptibility to experimental autoimmune encephalomyelitis in a murine model. PLoS One 2014;9:e110838. doi:10.1371/journal.pone.0110838.

[51] Browne GJ, Fardilha M, Oxenham SK, Wu W, Helps NR, da Cruz E Silva O a B, et al. SARP, a new alternatively spliced protein phosphatase 1 and DNA interacting protein. Biochem J 2007;402:187-96. doi:10.1042/BJ20060600.

[52] Chiba T, Miyashita K, Sugoh T, Warita T, Inoko H, Kimura M, et al. IкBL, a novel member of the nuclear I $\mathrm{KB}$ family, inhibits inflammatory cytokine expression. FEBS Lett 2011;585:3577-81. doi:10.1016/j.febslet.2011.10.024.

[53] Semple JI, Brown SE, Sanderson CM, Campbell RD. A distinct bipartite motif is required for the localization of inhibitory kappaB-like (IkappaBL) protein to nuclear speckles. Biochem J 2002;361:489-96.

[54] Greetham D, Ellis CD, Mewar D, Fearon U, an Ultaigh SN, Veale DJ, et al. Functional characterization of NF-kappaB inhibitor-like protein 1 (NFkappaBIL1), a candidate susceptibility gene for rheumatoid arthritis. Hum Mol Genet 2007;16:3027-36. doi:10.1093/hmg/ddm261.

[55] Castiblanco J, Anaya J-M. The IkappaBL gene polymorphism influences risk of 
acquiring systemic lupus erythematosus and Sjögren's syndrome. Hum Immunol 2008;69:45-51. doi:10.1016/j.humimm.2007.11.008.

[56] de la Concha EG, Fernandez-Arquero M, Lopez-Nava G, Martin E, Allcock RJ, Conejero L, et al. Susceptibility to severe ulcerative colitis is associated with polymorphism in the central MHC gene IKBL. Gastroenterology 2000;119:1491-5. doi:10.1053/gast.2000.20258.

[57] Carmody RJ, Ruan Q, Palmer S, Hilliard B, Chen YH. Negative regulation of toll-like receptor signaling by NF-kappaB p50 ubiquitination blockade. Science 2007;317:6758. doi:10.1126/science.1142953.

[58] Riemann M, Endres R, Liptay S, Pfeffer K, Schmid RM. The IkappaB protein Bcl-3 negatively regulates transcription of the IL-10 gene in macrophages. J Immunol 2005;175:3560-8. doi:175/6/3560 [pii].

[59] Pène F, Paun A, Sønder SU, Rikhi N, Wang H, Claudio E, et al. The IкB family member Bcl-3 coordinates the pulmonary defense against Klebsiella pneumoniae infection. J Immunol 2011;186:2412-21. doi:10.4049/jimmunol.1001331.

[60] Poljak L, Carlson L, Cunningham K, Kosco-Vilbois MH, Siebenlist U. Distinct activities of p52/NF-kappa B required for proper secondary lymphoid organ microarchitecture: functions enhanced by Bcl-3. J Immunol 1999;163:6581-8.

[61] Khan KA, Coaquette A, Davrinche C, Herbein G. Bcl-3-regulated transcription from major immediate-early promoter of human cytomegalovirus in monocyte-derived macrophages. J Immunol 2009;182:7784-94. doi:10.4049/jimmunol.0803800.

[62] Haruta H, Kato A, Todokoro K. Isolation of a novel interleukin-1-inducible nuclear protein bearing ankyrin-repeat motifs. J Biol Chem 2001;276:12485-8. doi:10.1074/jbc.C100075200. 
[63] Ito T, Morimatsu M, Oonuma T, Shiina T, Kitamura H, Syuto B. Transcriptional regulation of the MAIL gene in LPS-stimulated RAW264 mouse macrophages. Gene 2004;342:137-43. doi:10.1016/j.gene.2004.07.032.

[64] Motoyama M, Yamazaki S, Eto-Kimura A, Takeshige K, Muta T. Positive and negative regulation of nuclear factor-kappaB-mediated transcription by IkappaB-zeta, an inducible nuclear protein. J Biol Chem 2005;280:7444-51. doi:10.1074/jbc.M412738200.

[65] Kitamura H, Matsushita Y, Iwanaga T, Mori K, Kanehira K, Fujikura D, et al. Bacterial lipopolysaccharide-induced expression of the IkappaB protein MAIL in Blymphocytes and macrophages. Arch Histol Cytol 2003;66:53-62. doi:10.1679/aohc.66.53.

[66] Seshadri S, Kannan Y, Mitra S, Parker-Barnes J, Wewers MD. MAIL regulates human monocyte IL-6 production. J Immunol 2009;183:5358-68. doi:10.4049/jimmunol.0802736.

[67] Kayama H, Ramirez-Carrozzi VR, Yamamoto M, Mizutani T, Kuwata H, Iba H, et al. Class-specific regulation of pro-inflammatory genes by MyD88 pathways and IkappaBzeta. J Biol Chem 2008;283:12468-77. doi:10.1074/jbc.M709965200.

[68] Hildebrand DG, Alexander E, Hörber S, Lehle S, Obermayer K, Münck N-A, et al. $\mathrm{I} \kappa \mathrm{B} \zeta$ is a transcriptional key regulator of CCL2/MCP-1. J Immunol 2013;190:4812-20. doi:10.4049/jimmunol.1300089.

[69] Zhu J, Weinberg R, Wu X, Gowda NM, Muta T, Gowda DC. Iкb- $\zeta$ plays an important role in the ERK-dependent dysregulation of malaria parasite GPI-induced IL-12 expression. IUBMB Life 2012;64:187-93. doi:10.1002/iub.592.

[70] Niida $T$, Isoda $\mathrm{K}$, Kitagaki $\mathrm{M}$, Ishigami $\mathrm{N}$, Adachi $\mathrm{T}$, Matsubara $\mathrm{O}$, et al. IкBNS 
regulates interleukin-6 production and inhibits neointimal formation after vascular injury in mice. Cardiovasc Res 2012;93:371-9. doi:10.1093/cvr/cvr323.

[71] Bauer A, Villunger A, Labi V, Fischer SF, Strasser A, Wagner H, et al. The NFkappaB regulator Bcl-3 and the $\mathrm{BH} 3$-only proteins Bim and Puma control the death of activated T cells. Proc Natl Acad Sci U S A 2006;103:10979-84. doi:10.1073/pnas.0603625103.

[72] Mühlbauer M, Chilton PM, Mitchell TC, Jobin C. Impaired Bcl3 up-regulation leads to enhanced lipopolysaccharide-induced interleukin (IL)-23P19 gene expression in IL10(-/-) mice. J Biol Chem 2008;283:14182-9. doi:10.1074/jbc.M709029200.

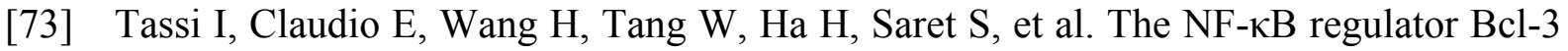
governs dendritic cell antigen presentation functions in adaptive immunity. $\mathrm{J}$ Immunol 2014;193:4303-11. doi:10.4049/jimmunol.1401505.

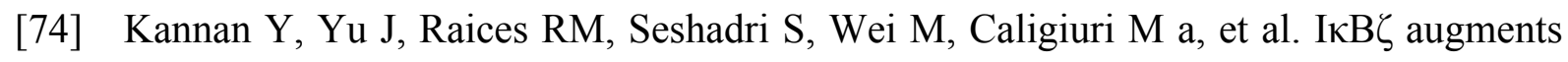
IL-12- and IL-18-mediated IFN- $\gamma$ production in human NK cells. Blood 2011;117:2855-63. doi:10.1182/blood-2010-07-294702.

[75] Zhang Q, Zhao K, Shen Q, Han Y, Gu Y, Li X, et al. Tet2 is required to resolve inflammation by recruiting Hdac2 to specifically repress IL-6. Nature 2015;525:38993. doi:10.1038/nature15252.

[76] Fujita S, Seino K, Sato K, Sato Y, Eizumi K, Yamashita N, et al. Regulatory dendritic cells act as regulators of acute lethal systemic inflammatory response. Blood 2006;107:3656-64. doi:10.1182/blood-2005-10-4190.

[77] Chiba T, Matsuzaka Y, Warita T, Sugoh T, Miyashita K, Tajima A, et al. NFKBIL1 confers resistance to experimental autoimmune arthritis through the regulation of dendritic cell functions. Scand J Immunol 2011;73:478-85. doi:10.1111/j.1365- 
3083.2011.02524.x.

[78] Zhang X, Paun A, Claudio E, Wang H, Siebenlist U. The tumor promoter and NF-kB modulator Bcl-3 regulates splenic B cell development. J Immunol 2013;191:5984-92. doi:10.4049/jimmunol.1300611.

[79] Hövelmeyer N, Wörns M a, Reissig S, Adams-Quack P, Leclaire J, Hahn M, et al. Overexpression of Bcl-3 inhibits the development of marginal zone B cells. Eur $\mathrm{J}$ Immunol 2014;44:545-52. doi:10.1002/eji.201343655.

[80] Rangelova S, Kirschnek S, Strasser A, Häcker G. FADD and the NF-kappaB family member Bcl-3 regulate complementary pathways to control T-cell survival and proliferation. Immunology 2008;125:549-57. doi:10.1111/j.1365-2567.2008.02869.x.

[81] Mitchell TC, Hildeman D, Kedl RM, Teague TK, Schaefer BC, White J, et al. Immunological adjuvants promote activated $\mathrm{T}$ cell survival via induction of Bcl-3. Nat Immunol 2001;2:397-402. doi:10.1038/87692.

[82] Bassetti MFJ, White J, Kappler JW, Marrack P. Transgenic Bcl-3 slows T cell proliferation. Int Immunol 2009;21:339-48. doi:10.1093/intimm/dxp002.

[83] Chilton PM, Mitchell TC. CD8 T cells require Bcl-3 for maximal gamma interferon production upon secondary exposure to antigen. Infect Immun 2006;74:4180-9. doi:10.1128/IAI.01749-05.

[84] Corn R a, Hunter C, Liou H-C, Siebenlist U, Boothby MR. Opposing roles for RelB and Bcl-3 in regulation of T-box expressed in T cells, GATA-3, and Th effector differentiation. J Immunol 2005;175:2102-10. doi:10.4049/jimmunol.175.4.2102.

[85] Tang W, Wang H, Claudio E, Tassi I, Ha H, Saret S, et al. The oncoprotein and transcriptional regulator Bcl-3 governs plasticity and pathogenicity of autoimmune $\mathrm{T}$ cells. Immunity 2014;41:555-66. doi:10.1016/j.immuni.2014.09.017. 
[86] Garg A V., Amatya N, Chen K, Cruz JA, Grover P, Whibley N, et al. MCPIP1 Endoribonuclease Activity Negatively Regulates Interleukin-17-Mediated Signaling and Inflammation. Immunity 2015;43:475-87. doi:10.1016/j.immuni.2015.07.021.

[87] Jeltsch KM, Hu D, Brenner S, Zöller J, Heinz G a, Nagel D, et al. Cleavage of roquin and regnase- 1 by the paracaspase MALT1 releases their cooperatively repressed targets to promote $\mathrm{T}(\mathrm{H}) 17$ differentiation. Nat Immunol 2014;15:1079-89. doi:10.1038/ni.3008.

[88] MaruYama T, Kobayashi S, Ogasawara K, Yoshimura A, Chen W, Muta T. Control of IFN- $\gamma$ production and regulatory function by the inducible nuclear protein $I \kappa B-\zeta$ in $T$ cells. J Leukoc Biol 2015;98:385-93. doi:10.1189/jlb.2A0814-384R.

[89] Hijioka K, Matsuo S, Eto-Kimura A, Takeshige K, Muta T. Induction of the nuclear IkappaB protein IkappaB-zeta upon stimulation of B cell antigen receptor. Biochem Biophys Res Commun 2007;356:476-80. doi:10.1016/j.bbrc.2007.03.002.

[90] Marson A, Kretschmer K, Frampton GM, Jacobsen ES, Polansky JK, MacIsaac KD, et al. Foxp3 occupancy and regulation of key target genes during T-cell stimulation. Nature 2007;445:931-5. doi:10.1038/nature05478.

[91] An J, Nakajima T, Shibata H, Arimura T, Yasunami M, Kimura A. A novel link of HLA locus to the regulation of immunity and infection: NFKBIL1 regulates alternative splicing of human immune-related genes and influenza virus $\mathrm{M}$ gene. J Autoimmun 2013;47:25-33. doi:10.1016/j.jaut.2013.07.010. 


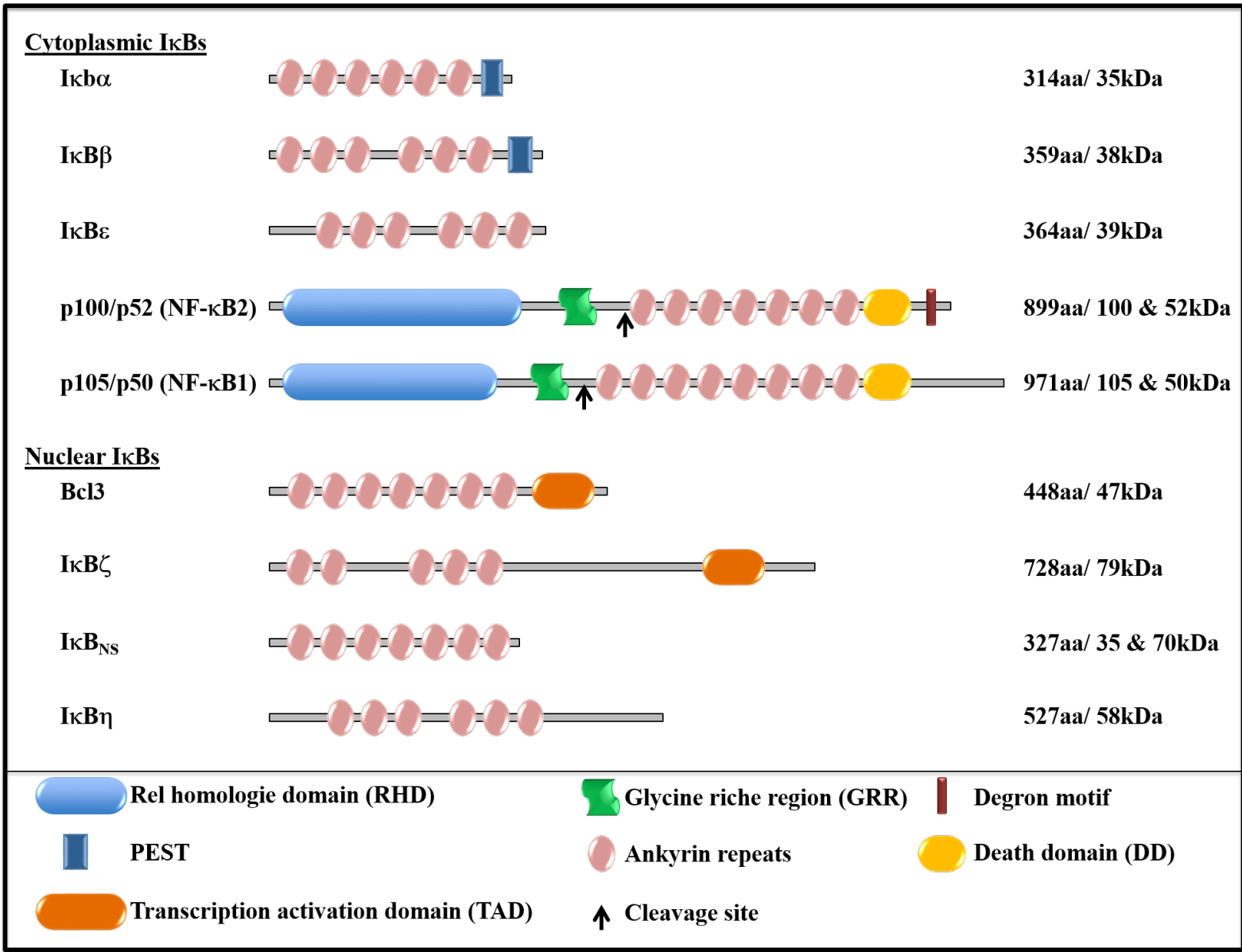

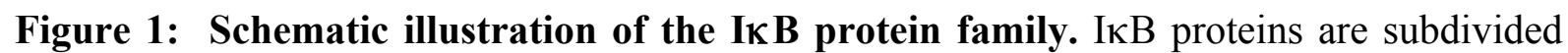
according to their location into cytoplasmic and nuclear IкBs. Their common feature is the existence of an ankyrin repeat domain (ARD), composed of six to eight single ankyrin repeats (ANK). 

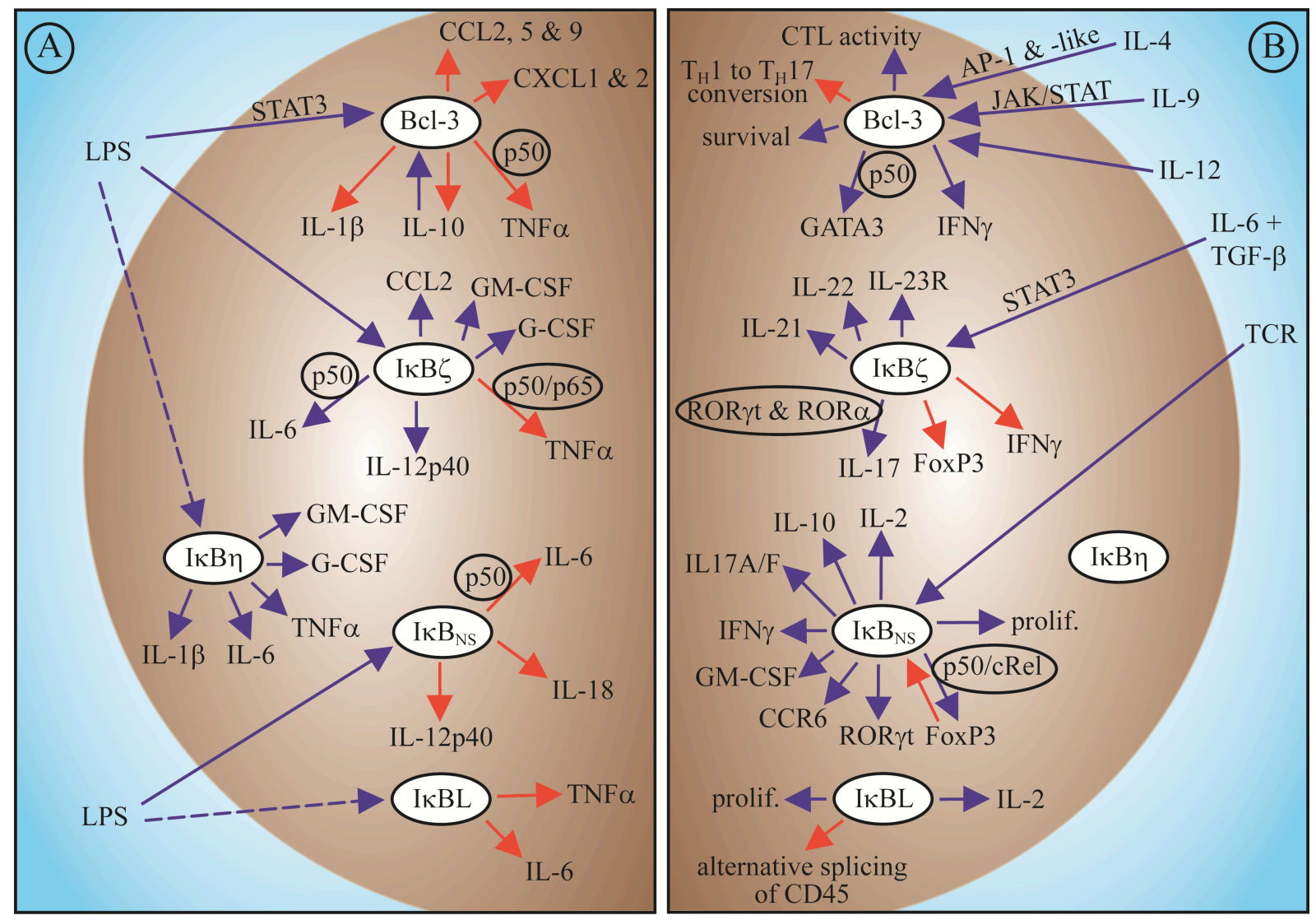

Figure 2: Known functions of nuclear $\mathbf{I} K B$ proteins in macrophages and $T$ cells. In macrophages (A) the expression of all nuclear IкB is induced by LPS-stimulation. In T cells (B) nuclear IкB protein expression was shown to be induced by divers stimuli. (A-B) Nuclear IкB proteins are shown in white circles and their particular interaction partners are illustrated

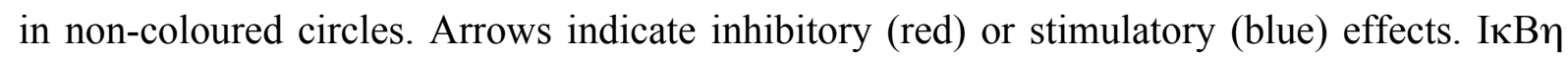
and IאBL are constitutively expressed and dotted arrows designate their partial induction. Prolif., proliferation. 
Table 1: General characteristics of nuclear IK B proteins.

\begin{tabular}{|c|c|c|c|c|}
\hline & Alternative protein name & Gene name & $\begin{array}{l}\text { Ankyrin } \\
\text { repeats }\end{array}$ & NF-кB specificity \\
\hline Bcl-3 & $\begin{array}{l}\text { B cell CLL/lymphoma } 3 \\
\text { protein }\end{array}$ & $B c l-3$ & $7[17]$ & p50, p52 [12,18,19] \\
\hline $\mathbf{I} \kappa \mathbf{B} \zeta$ & INAP, MAIL, NFKBIZ & Nfkbiz & $6[13]$ & p50, p65 [33,34,39] \\
\hline $\mathbf{I} \kappa \mathbf{B}_{\mathrm{NS}}$ & NFKBID, TA-NFKBH & Nfkbid & $7[14]$ & $\begin{array}{l}\text { p50 in RAW cells [44], } \\
\text { c-Rel and p65 in Treg [43], } \\
\text { p65, RelB and c-Rel [14] }\end{array}$ \\
\hline $\mathbf{I \kappa} \mathbf{B} \eta$ & ANKRD42, SARP & Ankrd42 & $8[15]$ & $\mathrm{p} 50[15]$ \\
\hline IкBL & LIST1, NFKBIL1 & Nfkbid & $2[16,52]$ & unknown \\
\hline
\end{tabular}


Table 2: Main targets of nuclear IK B proteins.

\begin{tabular}{|c|c|c|c|c|c|}
\hline & Macrophages & DCs & NK & $T$ cells & B cell \\
\hline Bcl-3 & $\begin{array}{l}\text { TNFa* }[22,24,57] ; \\
\text { IL-10 [22,57-59]; } \\
\text { IL-1 } \beta \text {, CXCL1, } \\
\text { CXCL2, CCL2, } \\
\text { CCL5, CCL9 [57]; } \\
\text { MIEP of } \\
\text { HCMV [61] }\end{array}$ & $\begin{array}{l}\text { IL-12p19 [31,72]; } \\
\text { IL-1 } \beta, \text { IL-6, } \\
\text { TNF- } \alpha[57] ; \\
\text { IL-12p40, } \\
\text { IL-12p70 [30]; }\end{array}$ & & IFN- $\gamma[83]$ & \\
\hline $\mathrm{I} \kappa \mathrm{B} \zeta$ & $\begin{array}{l}\text { TNF- } \alpha \text { [64]; } \\
\text { IL-6* [34,64,66,67]; } \\
\text { IL-12p40*[67]; } \\
\text { CCL2* [68]; } \\
\text { GM-CSF, } \\
\text { G-CSF [34]; } \\
\text { H3K4 [67] }\end{array}$ & $\begin{array}{l}\text { IL-6* }[36,75] ; \\
\text { IL-23 }[36]\end{array}$ & $\begin{array}{l}\text { IFN- } *^{*} \\
{[38,74]}\end{array}$ & $\begin{array}{l}\text { IL-17A*, } \\
\text { IL-21*, } \\
\text { IL-22*, } \\
\text { IL-23R* [42]; } \\
\text { IFN- } \gamma[88]\end{array}$ & $\begin{array}{l}\text { IL-10, } \\
\text { CTLA4, } \\
\text { TNF- } \alpha, \\
\text { CD86, IgM, } \\
\text { IgG3 [35] }\end{array}$ \\
\hline $\begin{array}{l}\mathbf{I K}_{\mathbf{N}} \\
\mathrm{s}\end{array}$ & $\begin{array}{l}\text { IL-6*, IL-12p40, } \\
\text { IL-18 [44,45] }\end{array}$ & $\begin{array}{l}\text { IL-6, IL-12p40, } \\
\text { IL-12p70 [45] }\end{array}$ & IFN- $\gamma[46]$ & $\begin{array}{l}\text { IL-2, } \\
\text { IFN- } \gamma[46] ; \\
\text { IL-10*, } \\
\text { IL-17A, } \\
\text { IL-17F, } \\
\text { GM-CSF, } \\
\text { ROR } \gamma \mathrm{t}, \\
\text { CCR6 [49,50]; } \\
\text { FoxP3* [43] }\end{array}$ & $\begin{array}{l}\text { IgM, } \\
\text { IgG3 }[47,48]\end{array}$ \\
\hline $\mathbf{I K} \mathbf{B \eta}$ & $\begin{array}{l}\text { IL-1 } \beta, \text { IL-6, TNF- } \alpha \text {, } \\
\text { G-CSF, } \\
\text { GM-CSF [15] }\end{array}$ & & & CD45 [91] & \\
\hline IK BL & IL-6, TNF- $\alpha[52]$ & $\begin{array}{l}\text { IL-2, IL-6, } \\
\text { TNF- } \alpha \text { [77] }\end{array}$ & & IL-2 [77] & \\
\hline
\end{tabular}

Marked $(*)$ proteins were shown to be regulated by interaction of the respective IкB protein with their gene locus. 